\title{
TREATMENT OF LANDFILL LEACHATE AT A REMOTE CLOSED LANDFILL SITE ON THE ISLE OF WIGHT
}

\author{
Tim Robinson * \\ Phoenix Engineering, Phoenix House, Scarne Mill Industrial Estate, Launceston, Cornwall, PL15 9GL, United Kingdom
}
Article Info:
Received:
1 November 2019
Revised:
5 March 2020
Accepted:
11 March 2020
Available online:
30 March 2020
Keywords:
Biological treatment
Landfill leachate
Leachate treatment
Nitrification
Wastewater treatment

\begin{abstract}
Safe treatment and disposal of leachates is an important issue at many old landfill sites, where the ingress of rainfall or groundwater is a significant issue requiring consideration. Such leachates may typically be relatively weak, but flows are often characterised by large seasonal variations, in response to winter rainfall. This paper compiles and presents long-term data from a case study on the Isle of Wight, UK. This paper highlights how a successful treatability trial using representative leachates can help predict the effectiveness of a large-scale treatment plant when treating landfill leachates biologically. Bleakdown leachate treatment plant effectively removes all concentrations of ammoniacal-N within the weak leachate generated by the site, ensuring that the discharge consent set by the Environment Agency is achieved consistently. The site is completely unmanned and remote, where monitoring technicians are only required to attend site twice per month in order to assess the success of the biological process. Through an online SCADA control system, operation of the treatment plant can be monitored and controlled remotely, trends in results can be observed, and daily data and treatment records downloaded. This treatment plant is an example of how leachate from old closed landfills can be effectively managed, with very low costs of operation, maintenance and site attendance. This paper presents comprehensive analytical and volumetric treatment data from the Bleakdown LTP, before presenting practical steps that would enable this success to be replicated at similar remote closed landfill sites.
\end{abstract}

\section{INTRODUCTION}

The Bleakdown landfill site is located approximately $7 \mathrm{~km}$ south of Newport, on the Isle of Wight. The site comprises an infilled sand and gravel pit, which received inputs of domestic, commercial, and non-hazardous industrial wastes, as well as inert, construction and demolition wastes, between 1977 and 1998. There was no engineered lining of the base, and the site was designed to operate on the "dilute and disperse" principle that was widely adopted at that time. There are three locations where leachates are currently being intercepted and collected at the Bleakdown site. Leachate quality is surprisingly consistent at each location, showing relatively small seasonal variations in strength.

It is primarily the dilute nature of the Bleakdown leachate that distinguishes this case study from more typical leachate treatment projects. The weaker characteristics of the leachate at Bleakdown compared to other landfill sites are considered throughout the report, particularly when discussing the different blends of leachate that were sampled through the Bleakdown treatability trials initially, before samples were regularly taken after the full-scale treatment plant was commissioned.

Because of the implications for the sustainability of the biomass within the treatment process, it is very important to highlight the low ratio of ammoniacal- $\mathrm{N}\left(\mathrm{NH}_{4}-\mathrm{N}\right)$ when compared to the combined iron ( $\mathrm{Fe}$ ) and calcium ( $\mathrm{Ca}$ ) concentrations. Due to the low potential for biological sludge growth, it was important to highlight to the client that occasional supplementation of biological sludge may well be required by the treatment process - this is often most beneficial on an annual basis, before wetter winter months.

Later in this paper, the anticipated sludge biomass growth rate will be considered using the information displayed in Table 1, in order to highlight such requirements.

Based on the results obtained from an extended leachate treatability trial performed during December 2015, it was concluded that a well-designed, but relatively simple SBR aerobic biological leachate treatment plant could readily and reliably achieve complete degradation of all biodegradable COD, and full nitrification of all ammoniacal-N, to produce an effluent suitable for direct discharge into a small local surface watercourse. During June 2017, Phoe- 
nix completely redesigned and refurbished an existing but ineffective treatment plant at Bleakdown, making several significant changes to the process and plant components, in order to provide consistent leachate treatment.

Plate 1 depicts the re-furbished leachate treatment plant following installation during June/July 2017. The three main tanks can be seen in the photograph below; the pre-existing Raw Leachate Balancing Tank (RLBT), the Treated Leachate Balancing Tank (TLBT), and the newly installed glass/epoxy fused steel tank that is operated as a modified Sequencing Batch Reactor (SBR), providing full nitrification of the leachate requiring treatment.

\section{PREVIOUS OPERATION OF THE TREATMENT PLANT}

The pre-existing leachate treatment plant at Bleakdown Landfill Site was not able to treat volumes of leachate being generated at the site either reliably or consistently, to achieve required discharge standards. This was partly because the plant was originally designed to treat only small volumes of leachates from the minor collection chambers at DP1 and DP2, rather than the newer leachate Sump which now produces increased volumes of stronger leachate.

The Sump collection point comprises a $1.2 \mathrm{~m}$ diameter sump which had been installed within a recently improved and cleaned out perimeter ditch, running from SW to NE towards the eastern boundary of the site. The sump contains an electric pump, which operates between high and low-level float switches, and pumps leachate in a westerly direction, through a 2-way electric solenoid valve that is able to divert sump leachate either to the leachate treatment plant, or for irrigation through a single pipeline. Plate 2 depicts the general location of the Sump and ditch at Bleakdown.
Pumping Chambers DP1 and DP2, are located along the eastern perimeter of the landfill, DP1 to the north end of the site, about $60 \mathrm{~m}$ SE of the leachate treatment plant, and DP2 nearly $300 \mathrm{~m}$ further south along the eastern boundary, just to the east of the main sump.

Each location represents a collection location for diluted leachates collected by various gravel-filled trenches/ French drains constructed along the eastern boundary of the landfill. These intercept surface breakouts of leachate, which probably represent perched water tables above the underlying clay layer at the base of landfilled wastes. Each chamber contains an electric pump, controlled by high and low-level float switches, which pumps leachate from within it to the leachate treatment plant, via connections into the pipeline mentioned earlier, that also pumps leachate from the Sump to the leachate treatment plant. Plates 3A and 3B show the DP1 and DP2 locations respectively.

Plate 4 displays the original layout of the treatment plant, where three tanks were used to collect and store leachate from only DP1 and DP2, before this was discharged to the local stream.

Figure 1 displays an aerial schematic of the landfill site, highlighting the three leachate pumping locations and also the location of the leachate treatment plant towards the North of the site. The leachate pumping lines from each collection location are also highlighted, where DP2 and the Sump location share a pipeline.

In the absence of any historic data for concentrations of ammoniacal- $\mathrm{N}$ in the blended leachate being treated, or any data for concentrations of nitrate-N or nitrite- $\mathrm{N}$ in treated leachate being discharged, it was difficult to know precisely the extent to which the previous plant was receiving or treating ammoniacal- $\mathrm{N}$ in the leachate. Nevertheless, during a period from September to Novem-

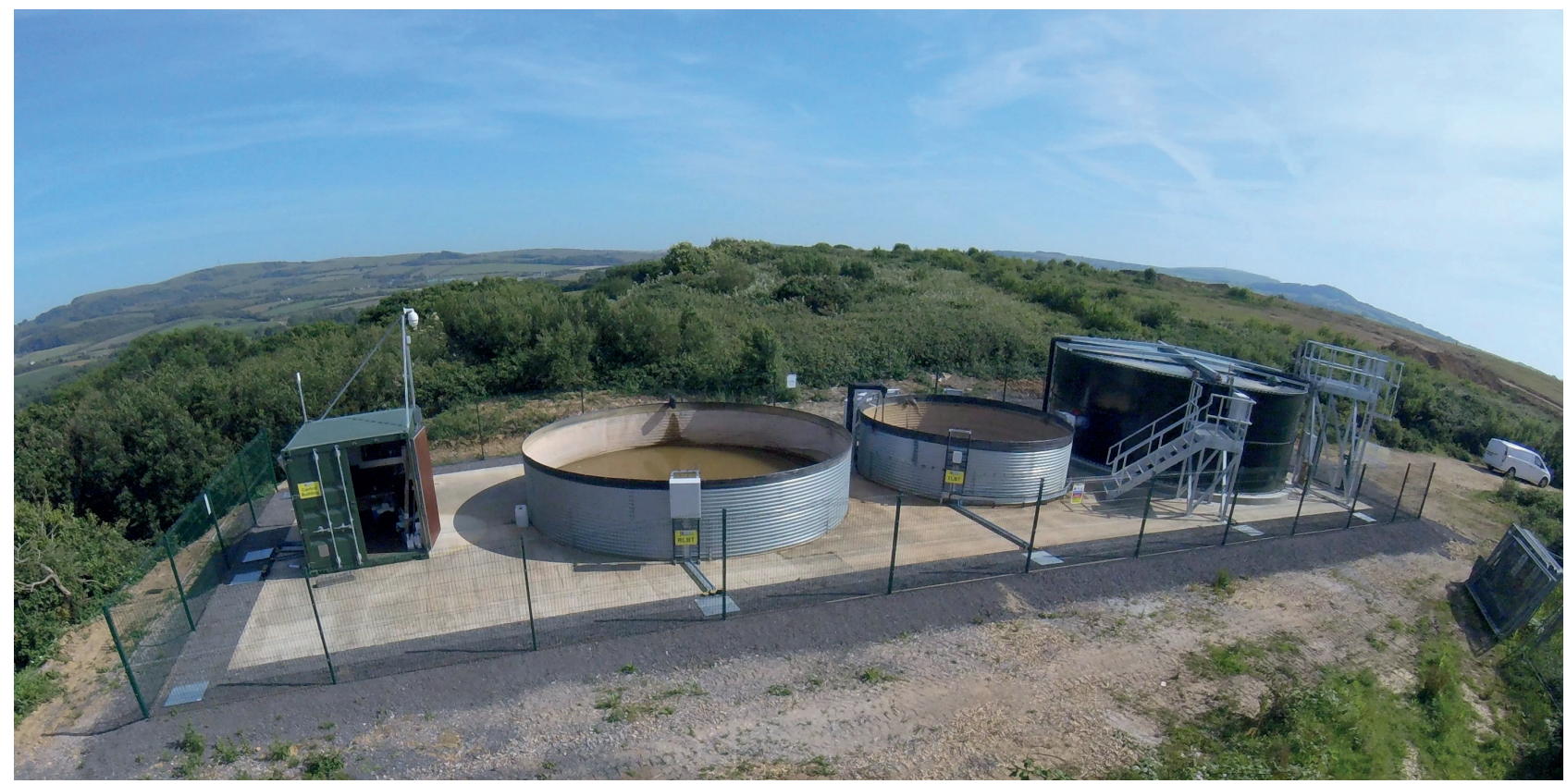

PLATE 1: Aerial photograph of the Bleakdown landfill leachate treatment plant (LTP), showing the control building, RLBT, TLBT, and new glass/epoxy fused steel SBR tank (left to right). 


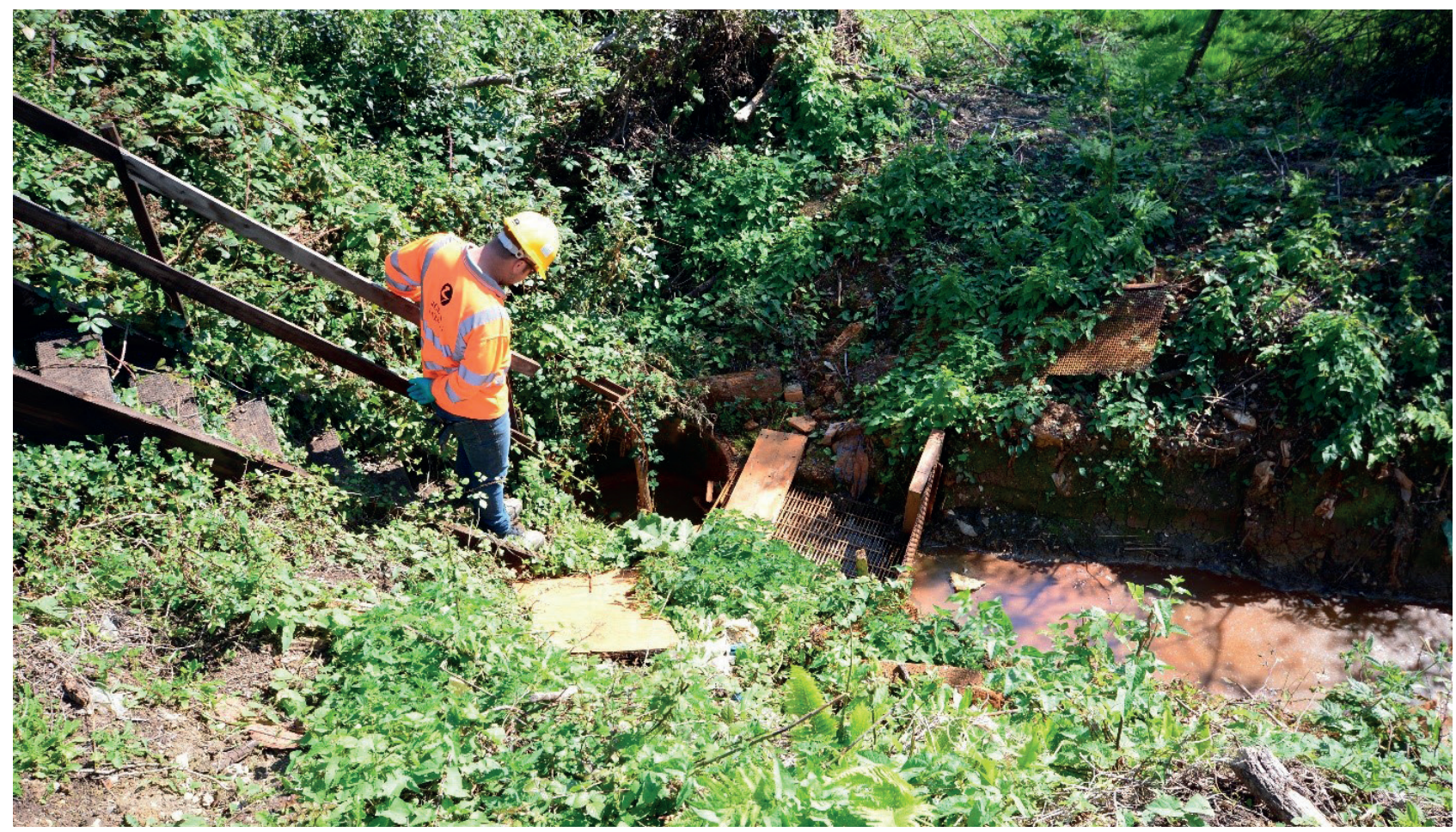

PLATE 2: General view of the more recently installed leachate collection point at the Sump on the Bleakdown landfill site.
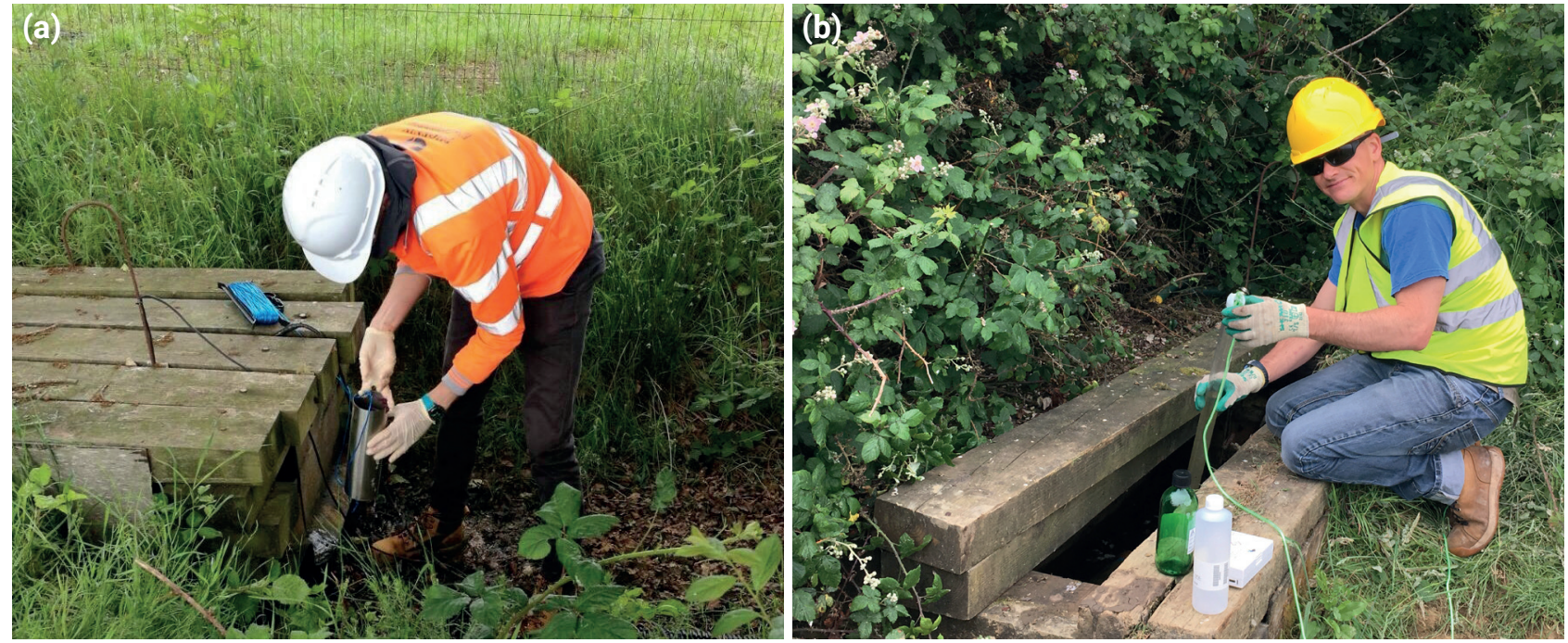

PLATE 3: (a) Sampling performed at DP1; (b) Routine sampling work at DP2.

ber 2014, when higher concentrations of ammoniacal-N in leachate collected at the Sump to the South East of the site were included in the raw leachate blend, treatment was clearly unsuccessful, with nearly $20 \mathrm{mg} / \mathrm{l}$ of ammoniacal- $\mathrm{N}$ found in the treated leachate failing the discharge consent significantly (an Environment Agency discharge consent had previously been set at $5 \mathrm{mg} / \mathrm{l})$. It was concluded that this was due to an inadequate treatment plant process design.

Average annual rainfall at Bleakdown during the six years prior to Phoenix's involvement in 2015 had been about $940 \mathrm{~mm}$. Over the 10 hectares of the completed land- fill site, it was therefore calculated that on average, about $94,000 \mathrm{~m}^{3}$ of rain had fallen per year. By the end of 2015 , it appeared likely that about $10,000 \mathrm{~m}^{3}$ of leachate may have been collected in total from DP1, DP2 and the Sump, representing just over 10 per cent of incident rainfall. This volume is more than twice that collected in 2014 , and more than three times that extracted during 2013. It was therefore clear that during recent years, and possibly all previous years, significant volumes of leachate had been generated, and were either accumulated within wastes, or (more likely) were leaving the site and being attenuated and diluted to an uncertain degree. 


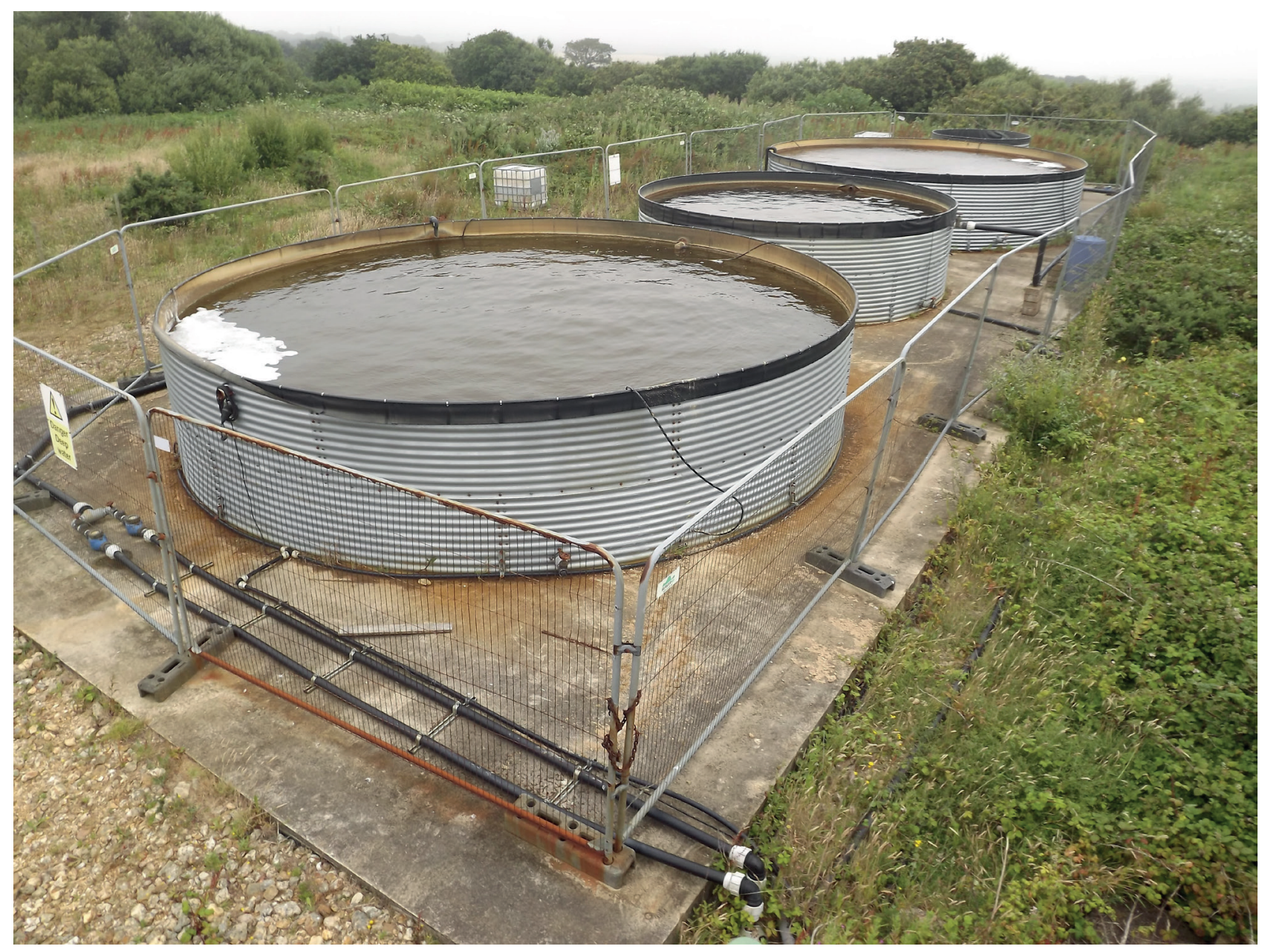

PLATE 4: The Bleakdown landfill leachate treatment plant (LTP) in July 2016, prior to refurbishment work.

For more than 12 months, from summer 2014, the significantly stronger leachate from the Sump location (making up the majority of all leachate being generated at Bleakdown) had therefore been excluded from treatment and was being spray irrigated onto the "restored" landfill surface (see Figure 1). At the time, it appeared likely that most of this leachate was simply infiltrating into wastes, and was being represented by significantly increasing overall rates of leachate generation. What was certain is that, having collected leachates from DP1, DP2 and the main Sump, it was going to be far better for all of the leachate to be treated reliably and discharged safely off-site in compliance with the discharge consent, rather than being reintroduced back into wastes through the cap, to reappear as increased leachate generation rates.

Since autumn 2014, weakest leachates from DP2 (mean ammoniacal-N of $2.2 \mathrm{mg} / \mathrm{l}$ ) comprised most of the leachate being passed through the pre-existing on-site treatment plant. This is the primary reason why "treated" leachate had historically consistently met the discharge consent value of $5 \mathrm{mg} / \mathrm{l}$ for ammoniacal- $\mathrm{N}$, although actually receiving minimal treatment.

From leachate flow data collected during 2015, it appeared that a full-scale plant at Bleakdown would be required to treat leachates at rates of up to 50 or $60 \mathrm{~m}^{3} / \mathrm{d}$ depending on seasonal rainfall variations, whilst average annual rates of 25 or $30 \mathrm{~m}^{3} / \mathrm{d}$ could be expected.

Phoenix considered all options for making use of the existing treatment plant infrastructure, as far as this was possible, to minimise costs of a new plant with an appropriate and modified process design. This upgraded treatment system would need to be completely automated, with full remote internet access enabling remote monitoring, operation and observation for this remote and unmanned site. The preferred and recommended option was that a new SBR tank be constructed to replace one of the pre-existing tanks on the existing concrete slab of the LTP. The other existing tanks were re-used as raw leachate balancing and feed tanks, as part of the new treatment process.

\section{SITE INVESTIGATIONS AND TREATABILI- TY TRIALS}

Before a new leachate treatment plant design could be constructed and commissioned at Bleakdown, detailed site investigations were necessary, in addition to the completion of thorough treatment trials on representative Bleakdown leachates. These site investigations and treatability trials were performed during late 2015 and early 2016. 


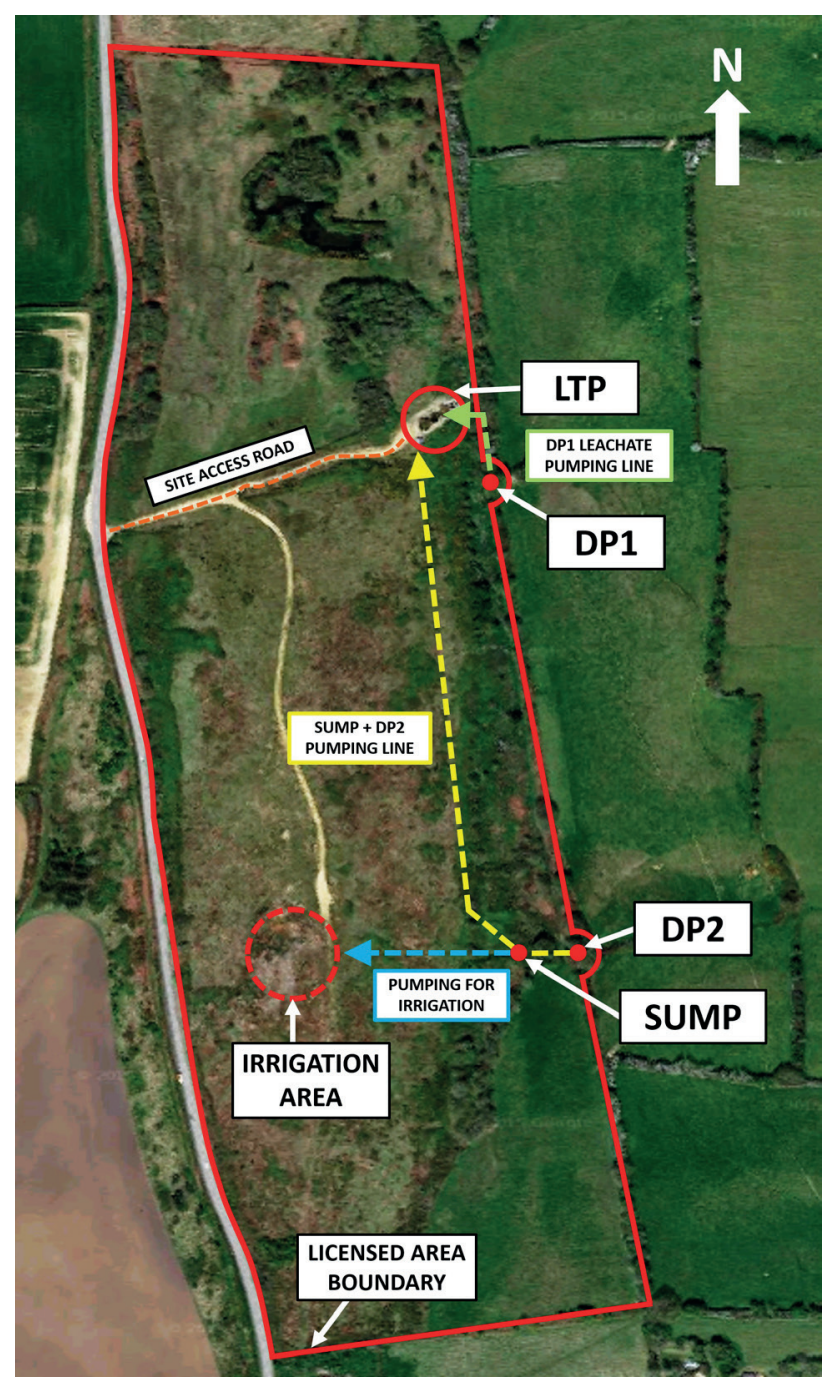

FIGURE 1: Satellite image of the Bleakdown landfill site and leachate treatment plant (LTP).

\subsection{Site investigations and reporting}

Preliminary site investigations revealed that there was no engineered lining of the base of the Bleakdown landfill site, and that the site was designed to operate on the "dilute and disperse" principle that was widely adopted at that time (e.g. see UK Department of the Environment, "Cooperative Programme of Research on the Behaviour of Hazardous Wastes in Landfill Sites: Policy Review Committee Final Report", April 1978). Nevertheless, sands and gravels were reportedly extracted down to the top of an underlying clay layer, which had been shown to exist in several areas of the site, and locally enables relatively diluted leachates to emerge around the site perimeter in some locations, particularly along its eastern boundary.

The landfill site runs north to south, is approximately $550 \mathrm{~m}$ long and $230 \mathrm{~m}$ wide, and has an approximate total surface area of about 9 or 10 hectares, over which wastes are typically up to $10 \mathrm{~m}$ deep. The highest point on the completed landfill surface is at an elevation of about $86 \mathrm{~m}$ AOD.

The site's Environmental Permit requires the site owners to submit an annual Environmental Monitoring Report, which details results that include monitoring of leachates and surface waters at the site.

\subsection{Treatability trials}

It was considered that a well-designed and relatively simple on-site plant could readily treat all leachates generated at Bleakdown, reliably and robustly. In order to demonstrate this, pilot-scale treatment trials were therefore undertaken on a representative blend of Bleakdown leachates (80\% from the Sump, $10 \%$ each from DP1 and DP2), which contained just over $20 \mathrm{mg} / \mathrm{l}$ of ammoniacal-N:

\begin{tabular}{c|c} 
Sampling location & Proportion of leachate included \\
\hline SUMP & $80 \%$ \\
\hline DP 1 & $10 \%$ \\
\hline DP 2 & $10 \%$ \\
\hline
\end{tabular}

Treatment during the trials was accomplished at mean hydraulic retention times of 1 day or less, using a relatively simple process design, consisting of a modified Sequencing Batch Reactor (SBR) with 8-hour and then 6-hour cycles, as Phoenix have installed at many similar sites. Those trials were operated at temperatures of between $12^{\circ} \mathrm{C}$ and $14^{\circ} \mathrm{C}$, which appeared realistic, based on experience at similar installations.

Leachate for use in the trials was collected from Bleakdown Landfill, on $20^{\text {th }}$ and $21^{\text {st }}$ October 2015, from each of the 3 discharge locations along the Western perimeter of the site, including the Sump and Discharge Points DP1 and DP2.

A total of 1,200 litres of leachate was collected in measured volumes, to be blended together for use as feedstock for the treatment trials. Leachate was transported to Phoenix's leachate laboratory in Launceston, Cornwall, where it was stored in a sealed container during the trials.

By mixing calculated proportions of leachate from each individual location, a representative blend of Bleakdown leachate was produced, to be used in Stage One, and then in Stage Two, of the treatment trials. The blended proportions of leachate from each of the three locations, making up the leachate feed for each stage of the trials, are summarised below.

These proportions were estimated prior to detailed examination of actual pumping data, and based on broad information. However, when such examination was completed and reported, it was clear that the blend of leachates used as feedstock for the treatability trials was entirely typical of the quality of leachate that an on-site plant would probably be required to treat for extended periods (see Table 1).

The Bleakdown treatability trials were seeded using 75 litres of mixed liquor, from biological sludge that had been collected and transported from Small Dole Leachate Treatment Plant near to Shoreham-on-Sea, on $22^{\text {nd }}$ October 2015. Because that sludge had been well acclimatised to similar leachate, relatively rapid establishment of successful treatment was anticipated for the new leachate feed. The initial mixed liquor that was aerated before the start of the trials, contained $12,300 \mathrm{mg} / \mathrm{l}$ suspended solids, but af- 
TABLE 1: Leachate blend quality used for the representative treatability trials on Bleakdown leachate.

\begin{tabular}{|c|c|c|c|}
\hline Sample ID & $\begin{array}{l}\text { Leachate } \\
\text { blend }\end{array}$ & $\begin{array}{c}\text { Day } 11 \\
\text { leachate feed }\end{array}$ & $\begin{array}{c}\text { Day } 15 \\
\text { leachate feed }\end{array}$ \\
\hline Sampled Date & $21 / 10 / 2015$ & $06 / 11 / 2015$ & $10 / 11 / 2015$ \\
\hline COD, unfiltered & 92.1 & 85.7 & 80.7 \\
\hline BOD, unfiltered & - & 28 & - \\
\hline $\begin{array}{l}\text { Total Organic } \\
\text { Carbon }\end{array}$ & 29.1 & 30.8 & 36.3 \\
\hline $\begin{array}{l}\text { conductivity } \\
(\mu \mathrm{S} / \mathrm{cm})\end{array}$ & - & 1,170 & - \\
\hline ammoniacal-N & 16.7 & 17.8 & 15.7 \\
\hline nitrate-N & 1.52 & 2.16 & 3.83 \\
\hline nitrite-N & 0.051 & 0.51 & 0.565 \\
\hline $\begin{array}{l}\text { alkalinity (as } \\
\mathrm{CaCO}_{3} \text { ) }\end{array}$ & 500 & 530 & 520 \\
\hline $\begin{array}{l}\text { Total Oxidised } \\
\text { Nitrogen }\end{array}$ & - & 2.67 & - \\
\hline $\mathrm{pH}$-value & - & 8.23 & - \\
\hline chloride & 108 & 124 & 120 \\
\hline sulphate & - & 21.2 & - \\
\hline phosphate as $P$ & - & $<0.05$ & - \\
\hline sodium & 69.9 & 89.3 & 74.8 \\
\hline magnesium & - & 25.6 & - \\
\hline potassium & - & 30.8 & - \\
\hline calcium & - & 149 & - \\
\hline chromium & - & 3.14 & - \\
\hline iron & 8.81 & - & - \\
\hline nickel & - & 5.53 & - \\
\hline copper & - & $<4$ & - \\
\hline zinc & - & 5.58 & - \\
\hline cadmium & - & $<0.5$ & - \\
\hline lead & - & $<0.5$ & - \\
\hline arsenic & - & 2.54 & - \\
\hline mercury & - & $<0.02$ & - \\
\hline manganese & - & 184 & - \\
\hline selenium & - & 4.88 & - \\
\hline
\end{tabular}

Notes: All results in $\mathrm{mg} / \mathrm{l}$, except $\mathrm{pH}$-value, conductivity $(\mu \mathrm{S} / \mathrm{cm})$ and heavy metals (in $\mu \mathrm{g} / \mathrm{l}$ ); Alkalinity as $\mathrm{CaCO}_{3}$; - = No Result; Analyses by ALS Ltd, Chester Laboratory.

ter desludging to a desired concentration, suspended solids within the aerated reactor remained fairly consistent at about $5,000 \mathrm{mg} / \mathrm{l}$ (375 grams total solids), from Day 5 until the end of the trials.

Concentrations of solids in mixed liquor within the aerobic reactor were tested for suspended solids (SS) every two or three days during the entire trial, and results were both replicable and consistent. In addition, samples were taken twice each week and submitted to ALS Laboratories for determination of both suspended solids (SS) and volatile suspended solids (VSS). The ALS results were also consistent and considered to be reliable. The sludge settled well and effluent clarified very well throughout the trial.

In full-scale leachate treatment plants treating strong and undiluted leachates from recently-emplaced wastes (e.g. 2,000mg/l of ammoniacal-N), mixed liquor would typically contain a ratio of VSS:SS of about 70 or 80 per cent. However, in leachates from old closed landfills, such as Small Dole and also Bleakdown, which contain significant concentrations of iron and calcium, greater levels of inorganic compounds in sludge, typically mean sludges contain only 20 or 25 per cent of VSS, as was the case for seed sludge collected and used in these trials.

Unlike SBR processes treating stronger leachates with high concentrations of ammoniacal- $\mathrm{N}(>1,000 \mathrm{mg} / \mathrm{l})$, where sludge growth and accumulation is common, it would probably not be necessary to allow for desludging of the fullscale SBR system at Bleakdown. In contrast, it would be likely that occasional further additions of biological sludge would occasionally be necessary.

By interpreting results presented in Table 1, the low ratio of ammoniacal- $\mathrm{N}$ to inorganic iron and calcium solids can be highlighted quantitatively. A mean ammoniacal- $\mathrm{N}$ concentration of $16.7 \mathrm{mg} / \mathrm{l}$ can be compared to the combined inorganic solids concentrations of iron $(8.81 \mathrm{mg} / \mathrm{l})$ and calcium (149 mg/l), which equates to a ratio of approximately 1:9.3. This ratio highlights an extremely low concentration of ammoniacal- $\mathrm{N}$ when compared to inorganic solids. In addition to this ratio, the low BOD of $28 \mathrm{mg} / \mathrm{I}$ within the leachate emphasises the potential requirement for occasional deliveries of fresh biological sludge, alongside possible accumulation of inorganic solids within the SBR.

Figure 2 presents data for suspended solids (SS) and volatile suspended solids (VSS) concentrations during the treatability trials. This figure highlights that although both SS and VSS did reduce during the first five days of the trial, consistent concentrations were met, which stabilised until the end of the trial. From these results it was concluded that, on a larger scale, the same phenomenon would be achieved, whereby a lower suspended solids and volatile suspended solids concentration could be maintained and effectively provide treatment over extended periods of up to 18 months (see Figure 17 presented later).

As anticipated, because the ratio of alkalinity to ammoniacal- $\mathrm{N}$ in raw leachate being treated was about 30:1 (530mg/l: 18mg/l), $\mathrm{pH}$-values remained consistent throughout the trial, meaning no additions of external alkalinity as sodium bicarbonate were required (see Figure 7 later). This is typical of leachates from older closed landfills, and considerably simplified design for on-site treatment of leachate at Bleakdown.

Figure 3 presents data for volumes of the Bleakdown leachate blend that were treated each day during Stage 1 and Stage 2 of the trials. Treatment began on the basis of three complete SBR cycles per day, of 8 hours each. At the end of Day 11, the operating system was modified so that four treatment cycles were fitted into 24 hours, which overcame hydraulic constraints imposed by the volume of treated leachate which could be decanted in any given cycle, and enabled significantly more leachate to be treated by the SBR setup. Figure 4 expresses these data as mean daily Hydraulic Retention Time (HRT) being achieved.

The treatment unit rapidly achieved flow rates in excess of 40 litres of leachate feed per day from the start of the tri- 


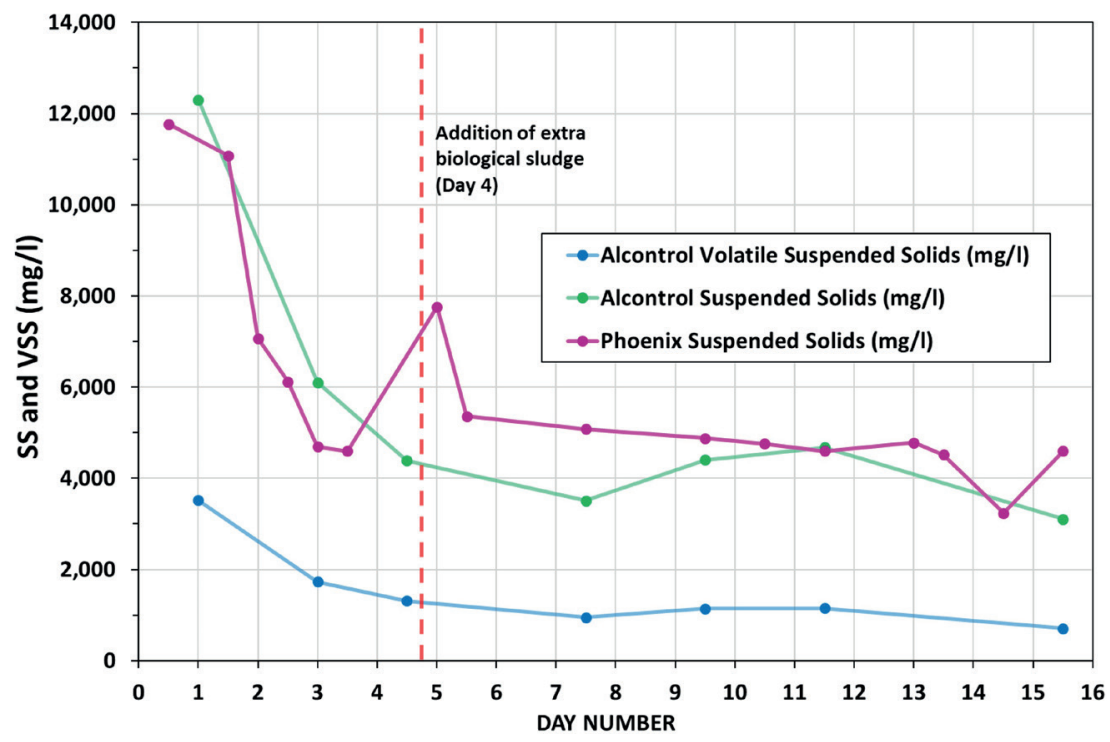

FIGURE 2: Concentrations of Suspended Solids and Volatile Suspended Solids during the treatability trials.

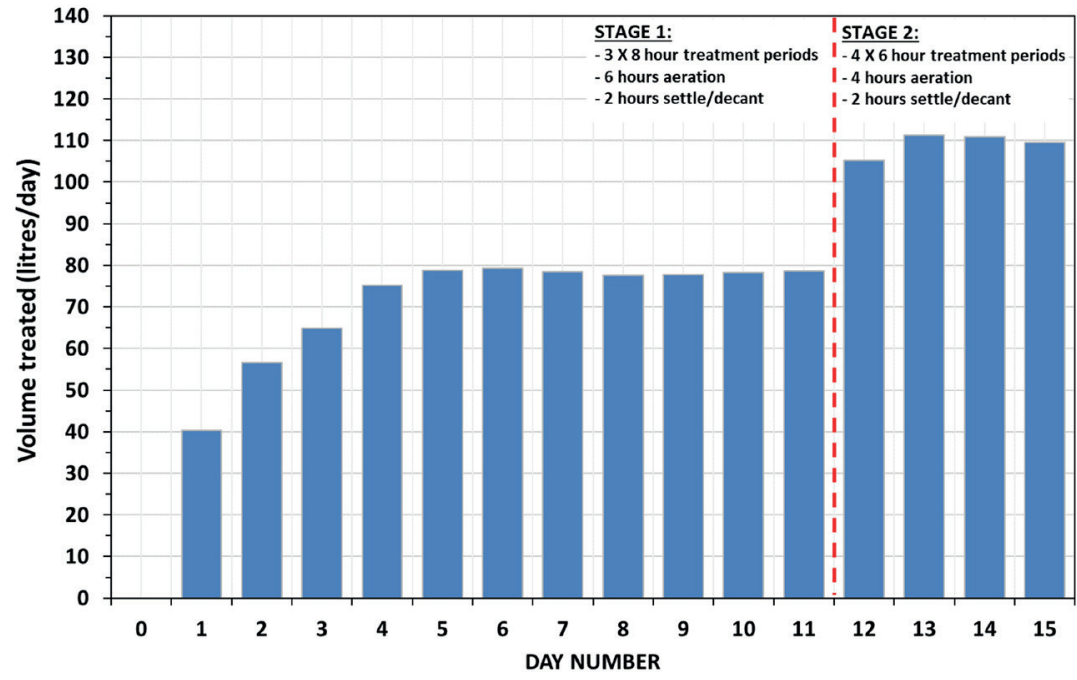

FIGURE 3: Volumes of leachate (litres) treated each day during the trials, days 0 to 15.

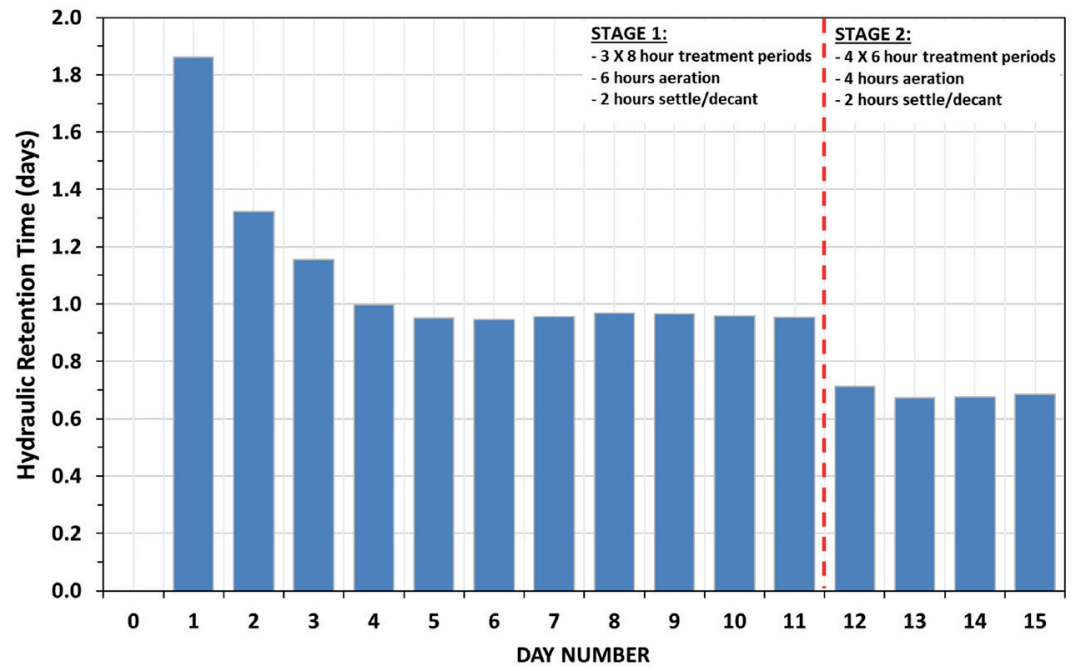

FIGURE 4: Mean Hydraulic Retention Time (days) during the trials, days 0 to 15. 
al, rising to exceed 75 litres per day within four days (mean HRT 1.33 days). From Day 4, more than 75 litres of leachate was treated on a daily basis, with an average daily volume of 78.0 litres fed from Day 4 until Day 11 (representing a mean HRT of 0.96 days). By Day 11 nearly 800 litres (785.7) of leachate had been treated in total, at an overall mean HRT of 1.09 days. The stability and consistency with which the trials operated is evident from all results and figures.

During Stage 2 of the trials, from Days 12 to 15, an additional 436.9 litres of leachate was fed and treated, with a mean daily feed volume of 109.2 litres achieved. At this point the mean Hydraulic Retention Time achieved was substantially below one day (mean HRT of 0.69 days).

Overall, 1222.6 litres of leachate were treated at mean rate of 81.5 litres per day, representing an overall mean hydraulic retention time (HRT) of 0.92 days. However, following the initial three days of increasing the leachate feed, the mean treatment rate was actually 88.4 litres per day (Mean HRT of 0.85 Days) during the final 12 days of the trial before leachate feed ran out. Treatment was stable at a mean HRT of less than 0.7 days during the last 4 days.

The treatment process adopted involved a relatively straightforward process design, comprising a modified Sequencing Batch Reactor (SBR) operated with cycle durations of initially 8 hours, and then 6 hours during the last 4 days of the trials. Leachate was treated at rates of up to 110 litres per day, in a reactor having a minimum hydraulic volume of 75 litres, achieving a minimum mean hydraulic retention time (HRT) of down to 0.7 days.

The trials were carried out for a total of 15 days, during which complete, precise and consistent treatment of leachate was maintained, with essentially full removal of ammoniacal-N (>98.5\%) by complete nitrification at all times. Figure 5 highlights successful nitrification of ammoniacal- $\mathrm{N}$ throughout the trials, where ammoniacal- $\mathrm{N}$ is removed whilst Nitrate- $\mathrm{N}$ is released.

Figure 6 shows that removal of degradable COD was minimal ( 10\%), however, with such a low initial COD concentration of $\sim 85 \mathrm{mg} / \mathrm{l}$, it was not necessary to remove significant amounts. In addition to this, COD was not listed as a parameter that required particular attention on the discharge consent set by the Environment Agency (see Table 2).

Very accurate data were obtained for alkalinity balance, which confirmed that it would not be necessary to add external alkalinity during treatment of the leachate, and considerably simplified design of the full-scale treatment plant. Figure 7 shows that $\mathrm{pH}$-value was maintained between 8.1 and 8.5 throughout the treatability trials. Because nitrification is an acid-generating process, in some cases it is necessary to add an alkali to the treatment process in order to raise the $\mathrm{pH}$. However, in this instance the leachate provided sufficient alkalinity to buffer any impact of nitrification on $\mathrm{pH}$-values within the reactor. This is common to the treatment of most weak leachates.

Throughout the treatability trial, the effluent clarified well, which provided an effluent containing low levels of suspended solids throughout the trial. This was an important factor when designing the full-scale treatment plant, because it showed that an effluent containing few solids would be discharged into a small, local watercourse.
The trials confirmed that a well-designed, modified SBR leachate treatment plant at Bleakdown would work reliably and consistently, and would require a treatment reactor with a mean Hydraulic Retention Time of less than 1 day. The next stage was therefore to design how this treatment process could be provided at full-scale, making best use of existing infrastructure from the previous plant. It was clear that a relatively small plant, based on the process design that had been tested during the trials could be developed for relatively low cost at Bleakdown.

\section{SITE REPORTING AND DETAILED DESIGN}

The refurbished leachate treatment plant (LTP) at Bleakdown Landfill was designed, constructed and commissioned as an aerobic biological suspended growth plant (Modified Sequence Batch Reactor SBR) during summer 2017. The treatment process adopted was one of biological nitrification. The design was based on information obtained during the comprehensive laboratory treatability trial.

The process design parameters used were adopted from the discharge permit, as outlined by the Environment Agency. These design parameters and loading concentrations are presented in Table 2.

As highlighted previously, leachates are generated from three locations at Bleakdown Landfill, which are termed "Sump", "DP1", and "DP2". At each of these three locations there was a pre-existing pump and pipeline leading to the refurbished leachate treatment plant. Leachate collected at these three points was to be pumped via the existing pumps and pipelines to the refurbished LTP, where it would be aerobically treated. Using the three existing leachate collection locations across the site, the new system is able to manage the incoming blend of leachate, by pumping this volume to a holding Raw Leachate Balancing Tank (RLBT) at the LTP.

Existing raw leachate collection systems and pipework were in good working order along the boundary of the existing reinforced concrete base, and no additional work was required, other than connection and integration into the new control system.

The new SBR comprises a circular glass/epoxy fused steel tank, with a nominal working volume of $122 \mathrm{~m}^{3}$ (Tank ID $7800 \mathrm{~mm}$, Height $3060 \mathrm{~mm}$ ). The top liquid depth is $2560 \mathrm{~mm}$ and the bottom liquid depth is $2240 \mathrm{~mm}$.

Figure 8 depicts the original process flow diagram that was outlined during the initial design phase of the new leachate treatment plant at Bleakdown, where leachate is received by the RLBT, before being fed into the SBR in controlled doses.

\section{CONSTRUCTION AND COMMISSIONING}

In order to install the new SBR reactor, a reinforced concrete base was constructed on top of the existing concrete foundations. The glass/epoxy coated steel tank was then placed onto the concrete pad, before steel steps, gantries and supports were fitted.

New pipelines were installed, lagged, and trace heated as required, in order to feed the correct tanks with leachate and discharge treated leachate to the main effluent dis- 


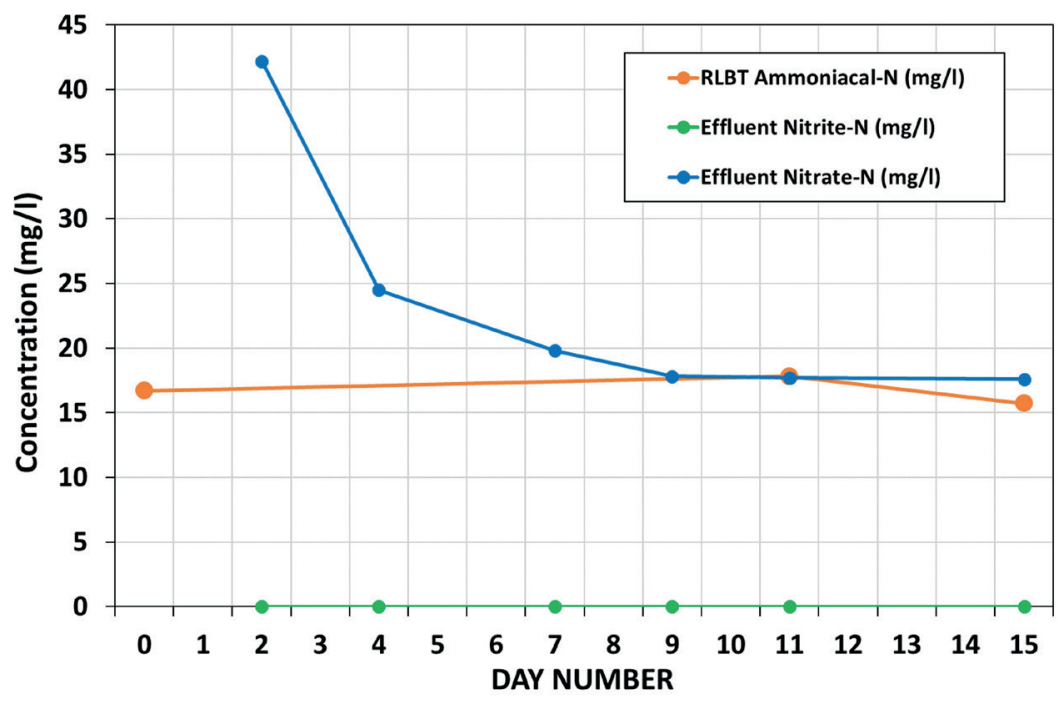

FIGURE 5: Raw leachate Ammoniacal-N concentrations compared to Effluent Nitrite-N and Nitrate- $\mathrm{N}$ concentrations.

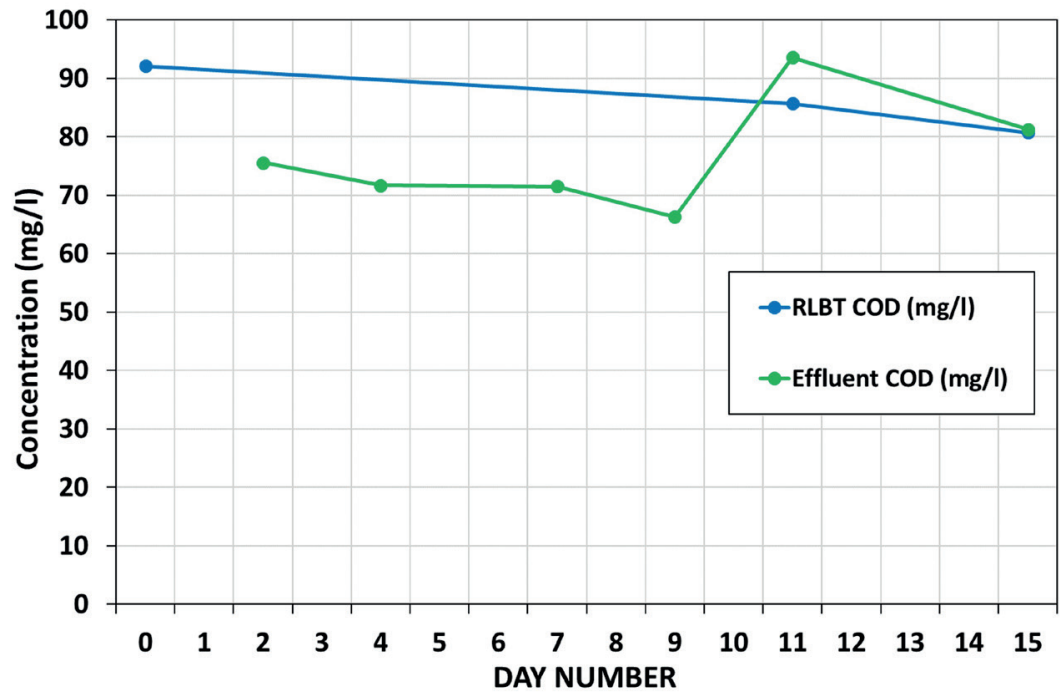

FIGURE 6: Raw leachate COD concentrations compared to Effluent COD concentrations.

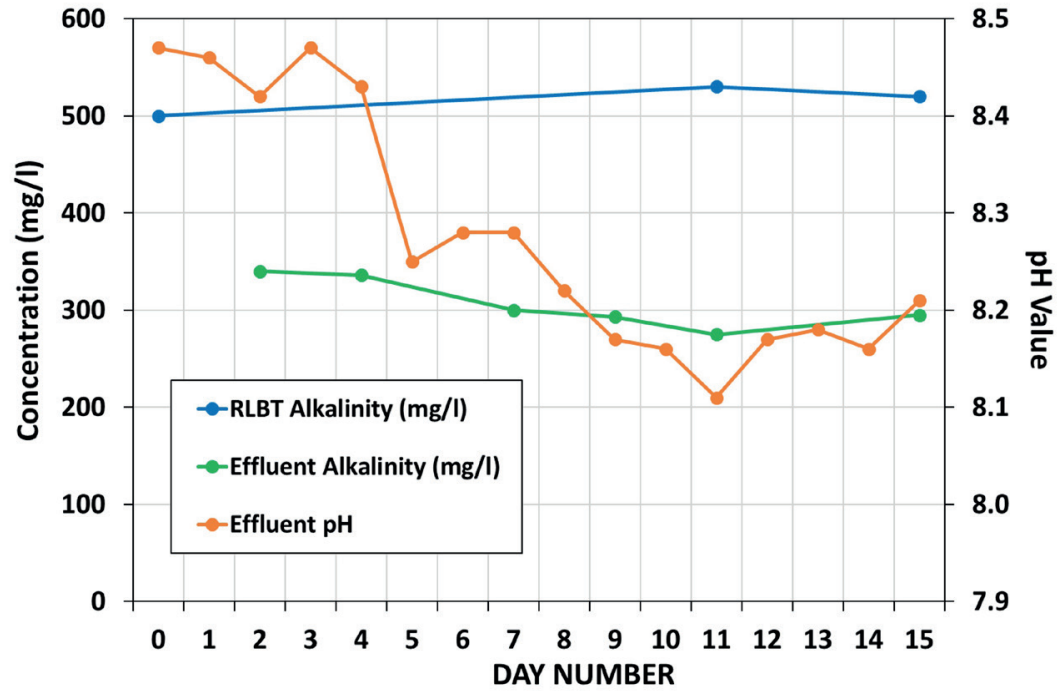

FIGURE 7: Raw leachate Alkalinity concentrations compared to effluent Alkalinity concentrations and pH. 
TABLE 2: Raw leachate concentrations, process design parameters, and discharge permit for bleakdown LTP.

\begin{tabular}{|c|c|c|c|}
\hline Determinand & $\begin{array}{c}\text { Design Blend } \\
\text { (Sump, DP1 \& DP2) }\end{array}$ & $\begin{array}{l}\text { Design Loading } \\
\text { at } 60 \mathrm{~m}^{3} / \mathrm{day}\end{array}$ & $\begin{array}{l}\text { Environment Agency } \\
\text { Discharge Permit }\end{array}$ \\
\hline COD & $100 \mathrm{mg} / \mathrm{l}$ & $\begin{array}{c}6 \mathrm{~kg} \\
\text { COD/day }\end{array}$ & N/A \\
\hline Ammoniacal- $\mathrm{N}$ as $\mathrm{N}$ & $20 \mathrm{mg} / \mathrm{l}$ & $\begin{array}{c}1.2 \mathrm{~kg} \\
\text { Ammoniacal-N/day }\end{array}$ & $\begin{array}{c}5 \mathrm{mg} / \mathrm{l} \\
\text { (as Ammonia) }\end{array}$ \\
\hline Alkalinity & $500 \mathrm{mgCaCO}_{3} / \mathrm{I}$ & $\begin{array}{c}\text { Not less than } \\
30 \mathrm{kgCaCO}_{3} / \text { day }\end{array}$ & N/A \\
\hline Suspended solids & $\mathrm{N} / \mathrm{A}$ & N/A & $130 \mathrm{mg} / \mathrm{l}$ \\
\hline Temperature & N/A & N/A & $25^{\circ} \mathrm{C}$ \\
\hline Iron (Fe) & $10 \mathrm{mg} / \mathrm{l}$ & N/A & $6 \mathrm{mg} / \mathrm{l}$ \\
\hline *PAH as Benzo (b) fluoranthene & $<0.1 \mathrm{ug} / \mathrm{l}$ & N/A & $0.1 \mathrm{ug} / \mathrm{l}$ \\
\hline $\mathrm{pH}$-Value & N/A & N/A & $6.0-8.5$ \\
\hline
\end{tabular}

* PAH as Benzo (b) fluoranthene: This was not tested during the treatability trials. However, data on concentrations present in the leachate were supplied by the employer. On most occasions the concentration was below the recorded limit of detection $<0.023 u g / l$. A marginally higher value of $<0.046 u g / I$ was recorded in the sump in February 2015 and January 2016. All these values are well below the Discharge Permit value of 0.1 ug/l, thus it is reasonable to assume a design blend value of $<0.1 \mathrm{ug} / \mathrm{l}$.

charge point. The pipelines were fitted with flowmeters, so that incoming and outflowing volumes of leachate/effluents could be measured and recorded accurately.

Following this work, all the electrical installation was completed, which involved fitting new valves (EAVs), flowmeters and instrumentation devices within the necessary tanks, before wiring these devices to control panels, and then back to the main control building. From the control building, the information from each device could be clearly displayed on the SCADA system.

Plate 5 shows the completed treatment plant during June 2017, following the biological commissioning. In the foreground the newly installed SBR tank is visible, which is used as the main treatment reactor. Following complete cleaning and refurbishment, the two pre-existing tanks were utilised as the RLBT and TLBT for raw leachate and treated leachate storage respectively. In the distance, the new control building is visible, at the end of the concrete foundations. The control building was constructed and fabricated within the small shipping container at Phoenix's premises in Cornwall, before being transported to site on the Isle of Wight. In order to enable monitoring on site,
CCTV was fitted to the control building, whilst $4 \mathrm{G}$ access enabled the SCADA and camera to be accessed remotely.

The treatment plant was biologically commissioned by Phoenix during June 2017, using seed sludge delivered from the same site in East Sussex which had provided seed sludge for the treatability trials. Thorough sampling work was carried out at the LTP and at the landfill leachate wells, which enabled the successful treatment process to be confirmed. Regular on-site analysis proved that all ammoniacal-N within the raw leachate feed was being removed through an effective nitrification process.

Once the treatment process had been established and was operating reliably, Phoenix were required to train up a local site technician, who would carry out fortnightly checks at the LTP and around the landfill. The technician would also perform routine monthly sampling of all leachate sources on the landfill site, in addition to a complete sampling suite at the LTP and the effluent discharge point. It was important that the site technician had a good understanding of the operation of the treatment plant, and the different reactors contributing to the process, particularly as between the fortnightly site visits the site would be

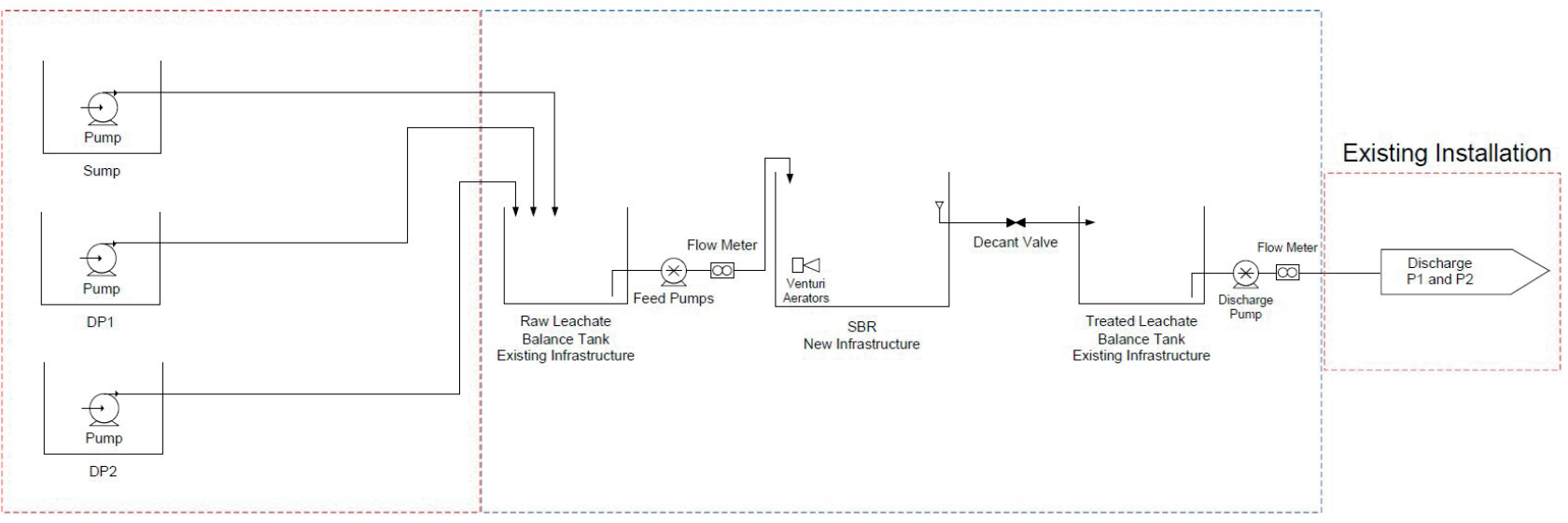

FIGURE 8: Process flow diagram for the new leachate treatment plant as installed at Bleakdown landfill. 
unmanned, and only checked by Phoenix through remote access to the SCADA system.

\section{OPERATION OF THE TREATMENT PLANT}

As is common at similar leachate treatment plants, the SBR was to be fed with frequent small volumes of leachate at regular 15-minute intervals throughout the aeration phase. At a design flow rate of $60 \mathrm{~m}^{3} /$ day for the SBR ( $15 \mathrm{~m}^{3} /$ cycle) the feed pump is on for just over 3 minutes during each feed. This leaves a rest period of 11 minutes before the next feed call. Pump duty of the two feed pumps alternates on the hour, quarter past the hour, half past the hour and quarter to the hour.

The LTP was designed for a treatment capacity of at least $60 \mathrm{~m}^{3}$ per day, but operates satisfactorily at a lower throughput rate, such as the permit constraint of $50 \mathrm{~m}^{3}$ per day, or less. The 6-hour treatment cycle consists of an Aeration and Leachate Feed Period (4 hours), followed by a Settlement Period ( 1 hour), during which the treated leachate is separated from the biomass. The clarified supernatant is then decanted during the Decant Period ( 1 hour), as final effluent. In summary, the 6-hour treatment cycle within the SBR is operated as follows in Figure 9.

In order to operate and monitor the treatment within the SBR at Bleakdown LTP, the new Phoenix design of the treatment plant included the following plant and instrumentation:

- 1 × $3 \mathrm{~kW}$ venturi aerator, to provide complete aeration, mixing, and some heat input to the SBR.

- A depth transducer and a pH-value sensor were installed in separate stilling tubes.

- A DO probe was also fitted to assess the effectiveness of the aeration cycle.

- Float switch and support bracket, to control maximum depth in the SBR.

This instrumentation is fed back to the SCADA system, in order to effectively present the operational data

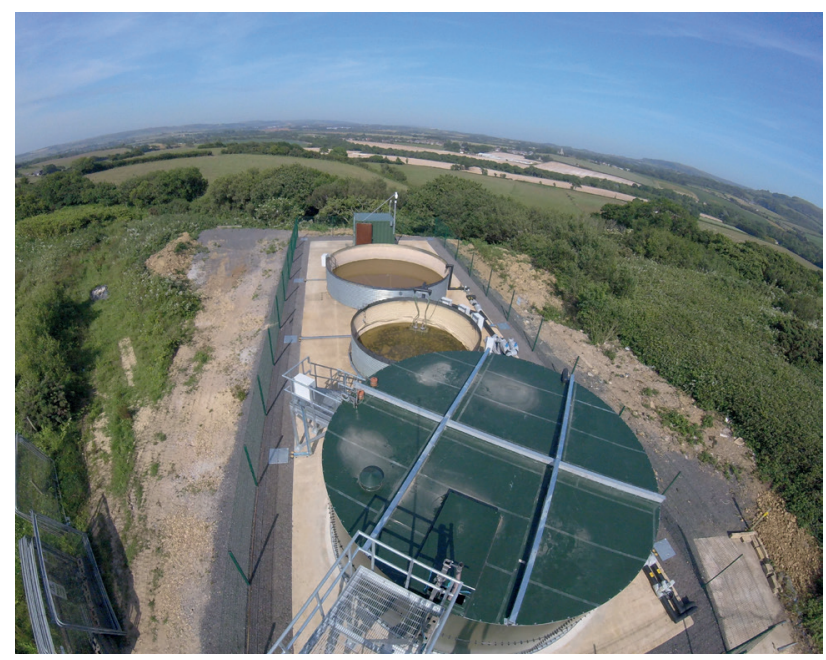

PLATE 5: The Bleakdown landfill leachate treatment plant (LTP) in June 2017, following the refurbishment works. in a way that it could be viewed through a computer remotely.

The SCADA also stores data from monitoring devices in addition to displaying information regarding the instantaneous status of the various plant systems. The SCADA displays logs and trends, making data available for downloading to removable and remote storage devices. The system is password protected and open to interrogation by only named individuals to prevent casual interference.

\section{ROUTINE TESTING, MONITORING AND REPORTING}

Following the outset of the operational contract in June 2017 , there was a requirement to provide regular reporting of the operation of the treatment plant. This reporting involved monthly sampling of all of the leachates, process waters and effluents being produced by the treatment plant, in addition to the final discharge at the main discharge point from the site.

Phoenix were also contracted to carry out regular fortnightly checks across the leachate pumping locations, as well as thorough observations at the leachate treatment plant.

Following the monthly sampling and routine observations of the treatment plant and landfill site, a monthly update report is required by the client, Aggregate Industries. This update report highlights all data obtained during the month via the SCADA, including incoming leachate volumes and discharged effluent volumes. Phoenix are also able to compile a record of rainfall and weather data, which is collected at a local Bleakdown weather reporting station.

Samples that have been taken by the subcontractor at the start of each month are couriered to a laboratory, and tested for a routine suite of determinands. The results from these analytical tests are then emailed to Phoenix in time for the compilation of the monthly reports. These analytical results are used to confirm basic and routine on-site test strip analyses, and to prove that the discharge consent is

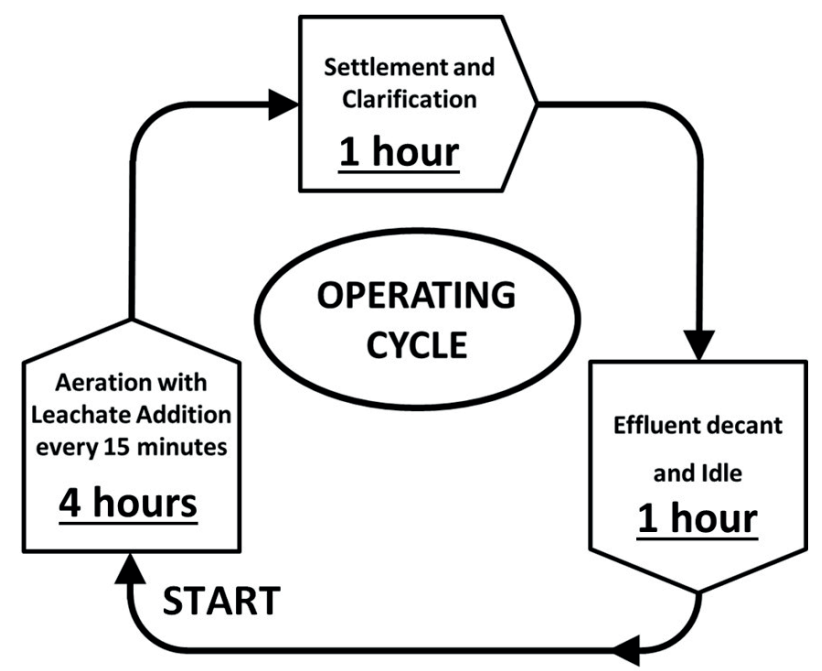

FIGURE 9: A single 6-hour treatment cycle, as performed four times every 24 hours at Bleakdown LTP. 
met on a monthly basis. These results are also useful for observing the changes in leachate strength on a seasonal basis, which will be discussed later in the report.

In addition to monthly reporting, Phoenix are required to make six-monthly and annual visits to site at Bleakdown, to perform six-monthly maintenance works. On an annual basis, a condition report is produced, highlighting any changes in the condition of the treatment plant or the landfill site. The maintenance visits involve testing all electrical supplies, control panels, instrumentation, flow meters and pumps on the site, in addition to arranging for engineers to visit site to test aerators and heavy-lifting apparatus.

Regular contact with Aggregate Industries is maintained, in order to communicate data on operation of the treatment plant, in addition to pointing out any areas of the site and treatment plant that may require repair or upgrade works.

\section{OPERATIONAL RESULTS FROM THE TREATMENT PLANT}

Since summer 2017, the Bleakdown treatment plant has performed successfully and the strict discharge consent at the site has consistently been met. During the two years since the new treatment plant was commissioned at Bleakdown, a complete record of analytical results, daily rainfall, and daily leachate volumes has been kept, which has enabled accurate observation of the plant's operation to be observed. Figure 10 presents monthly rainfall and treatment volumes, highlighting the impact that seasonal changes in rainfall has on COD and Ammoniacal-N loads.

\subsection{Rainfall data}

At the end of each month, rainfall and weather data from the local Bleakdown weather station is compiled and compared against leachate and effluent flows passing through the treatment plant.

Figure 10 compares historic average monthly rainfall data between 1981 and 2010, to more recent monthly data during the operational period of the upgraded leachate treatment plant at Bleakdown Landfill Site. Figure 10 highlights several distinctive trends in rainfall over previous years, which can be noted below:

- Seasonal changes in rainfall on an average annual basis between 1981 and 2010.

- An exceptionally wet January during 2016.

- A very wet summer period between May and September 2017.

- A very dry summer in 2018.

- Prolonged heavy rainfall between November and December 2018.

- A very dry January in 2019.

\subsection{Leachate flow volumes}

On a monthly basis, daily logs of leachate volumes pumped to the leachate treatment plant and effluent totals flowing from the discharge point can be downloaded and compiled using the remote SCADA system at Bleakdown. Observation of the leachate totals and effluent volumes is useful when considering the monthly rainfall volumes to see how volumes of rainfall influence leachate abstracted from the landfill site on a monthly basis.

Figure 11 highlights the changes in leachate volumes produced by the landfill site each month, during the operational period of the leachate treatment plant, from June 2017.

Figure 11 shows that the volumes of leachate abstracted at each pumping well are proportional to the changes in rainfall on a monthly basis. For example, following prolonged heavy rainfall during the winter of $2017 / 18$, leachate volumes produced by the site continued to increase until March 2018. Likewise, after heavy rainfall experienced in November and December 2018, the volumes of leachate abstracted from DP2 and the Sump pumping line showed a sudden increase in volumes of leachate generated.

\subsection{Analytical Data}

Analytical data obtained through monthly sampling highlight the consistent and reliable treatment process that has been observed at Bleakdown since the commissioning period in June 2017.

Table 3 highlights that all parameters originally set as part of the Environment Agency's discharge permit have been achieved consistently throughout the 2-year period of operation. Importantly, Ammoniacal-N has consistently been reduced to trace levels $(<0.2 \mathrm{mg} / \mathrm{l})$, whilst iron concentrations have always been significantly below the consented concentration of $6 \mathrm{mg} / \mathrm{l}$.

Figure 12 shows that complete nitrification has consistently been achieved at Bleakdown LTP since commissioning in June 2017. A mean concentration of $17 \mathrm{mg} / \mathrm{l}$ Ammoniacal-N is evident within the blend of leachate, which is fully nitrified to $17 \mathrm{mg} / \mathrm{l}$ (mean) of nitrate-N within the final effluent. This proves that the nitrification process being performed within the SBR reactor is being achieved successfully.

It is worth noting that Figure 12 highlights two periods where the concentrations of nitrate- $\mathrm{N}$ within the effluent spiked (September 2017 and July 2019). These results correspond with reseeding events (see Figure 17), where two different deliveries of biological sludge were made from a treatment plant where a leachate with a high ammoniacal- $\mathrm{N}$ was being treated (resulting in a high nitrate-N concentration within the sludge that was delivered to Bleakdown LTP).

Similar to the treatability trials, Figure 13 illustrates how removal of both $C O D$ and $B O D$ was minimal, from the raw leachate to the final effluent being discharged. This was not an issue at Bleakdown, because the raw leachate contained low concentrations of both COD and BOD, and no set discharge consent exists for either determinand. In the same way that ammoniacal-N spikes on two occasions in Figure 12, the same effect can be highlighted in COD concentrations in Figure 13, where COD in the effluent increases after the initial delivery of biological sludge, containing a higher concentration of non-degradable COD.

Figure 14 highlights how $\mathrm{pH}$ remains stable throughout treatment, whilst the levels of alkalinity within the raw leachate are sufficient to buffer the acid-generating nitrification process within the SBR, as was the case within the treatment tank during the treatability trial. At sites where 


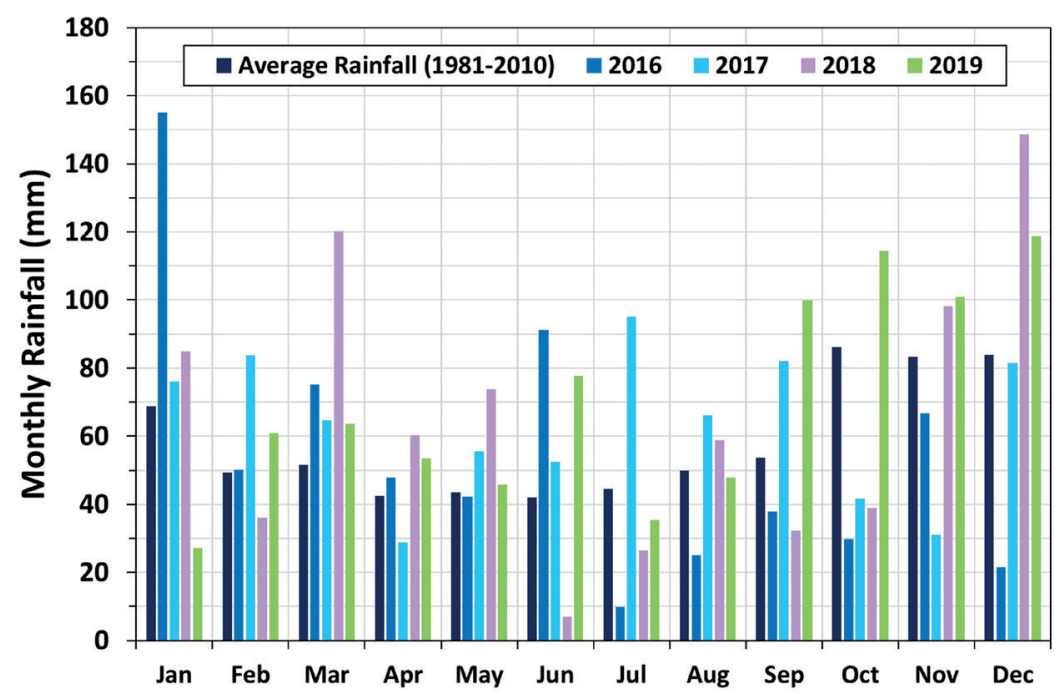

FIGURE 10: Average monthly rainfall volumes and recent monthly rainfall volumes experienced at Bleakdown LTP.

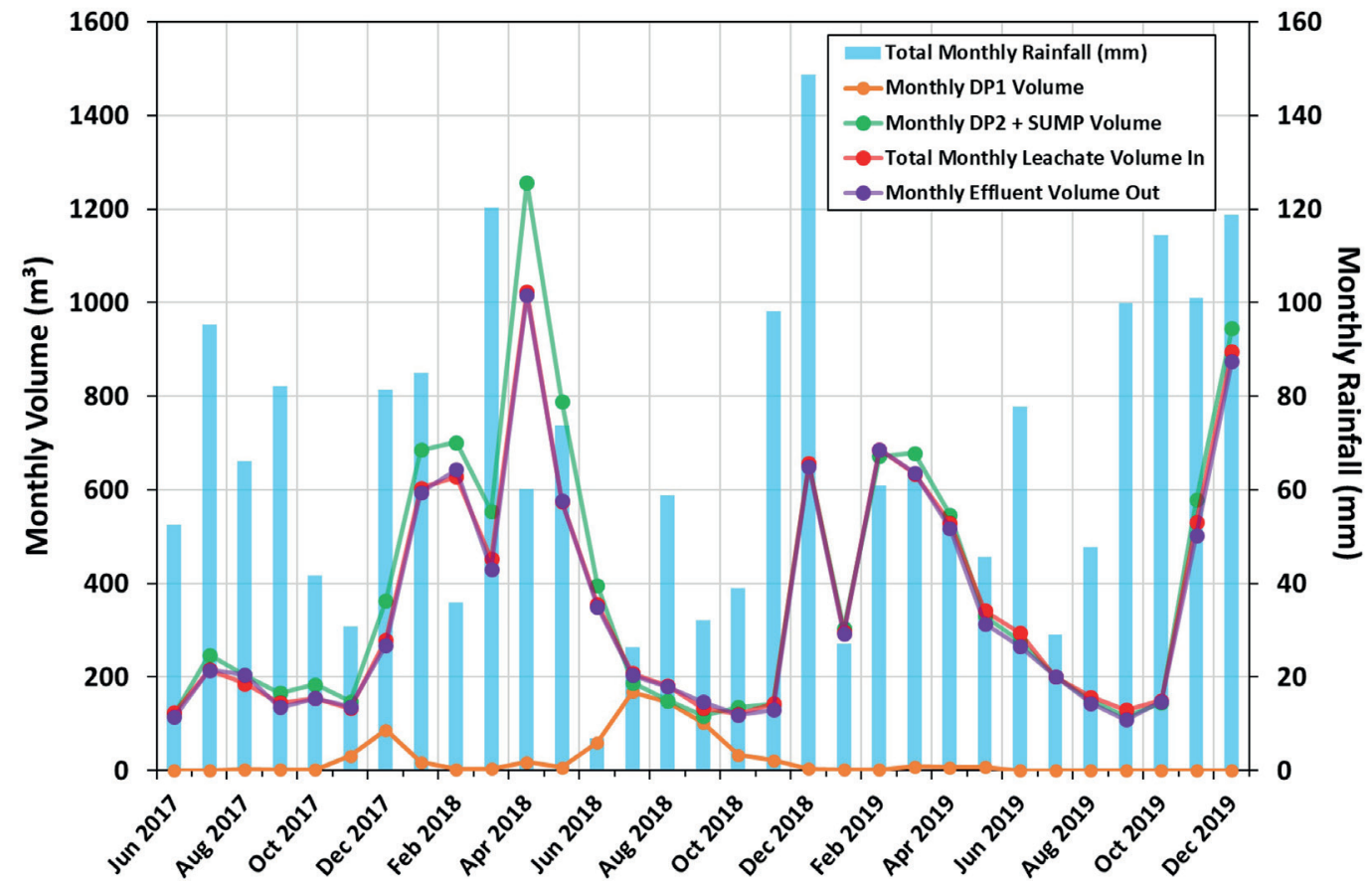

FIGURE 11: Monthly leachate volumes received at the LTP from each leachate pumping location, compared to the change in rainfall on a monthly basis.

stronger leachates are being treated, it is a necessity to add alkalinity to the nitrification treatment process.

\subsection{Contaminant loading within leachate at Bleak- down}

Using the monthly analytical data obtained from Bleakdown, the strength of leachate can be compared with volumes of leachate being produced, allowing loading calculations to be made. This means that observations can be made into how the strength of leachate varies on a seasonal basis, whilst also considering how this impacts the expected requirements of the treatment plant at different times of year.
Figure 15 and Figure 16 present the total volume of leachate treated by the LTP as bars, whilst Ammoniacal-N and $\mathrm{COD}$ are presented as lines on respective graphs. It is clear from these graphs that the loading of both COD and Ammoniacal-N is heavily influenced by the varying volumes of leachate being generated by the landfill site on a seasonal basis.

Table 4 shows that although Ammoniacal-N concentrations in raw leachate are influenced by the variations in rainfall and therefore dilution, COD values remains very similar throughout the year regardless of flow rates. Therefore, with a consistent COD value within the leachate, the COD loading is primarily influenced by the volume of lea- 
TABLE 3: Mean results for the performance of Bleakdown LTP since biological commissioning during June 2017.

\begin{tabular}{|c|c|c|c|}
\hline Design Parameter & $\begin{array}{l}\text { Mean Leachate Blend } \\
\text { (Sump, DP1 \& DP2) }\end{array}$ & Mean Effluent Quality & $\begin{array}{l}\text { Environment Agency } \\
\text { Discharge Permit }\end{array}$ \\
\hline COD & $92.6 \mathrm{mg} / \mathrm{l}$ & $107 \mathrm{mg} / \mathrm{l}$ & N/A \\
\hline Ammoniacal- $\mathrm{N}$ as $\mathrm{N}$ & $17.5 \mathrm{mg} / \mathrm{l}$ & $<0.2 \mathrm{mg} / \mathrm{l}$ & $5 \mathrm{mg} / \mathrm{l}$ (as Ammonia) \\
\hline Nitrate- $\mathrm{N}$ as $\mathrm{N}$ & N/A & $16.8 \mathrm{mg} / \mathrm{l}$ & N/A \\
\hline Nitrite-N as $\mathrm{N}$ & N/A & $0.5 \mathrm{mg} / \mathrm{l}$ & N/A \\
\hline Alkalinity & $548 \mathrm{mg} / \mathrm{l}$ & 342 mg/l & N/A \\
\hline Suspended Solids & N/A & $32.7 \mathrm{mg} / \mathrm{l}$ & $130 \mathrm{mg} / \mathrm{l}$ \\
\hline Temperature & $<25^{\circ} \mathrm{C}$ & $<25^{\circ} \mathrm{C}$ & $25^{\circ} \mathrm{C}$ \\
\hline Iron $(\mathrm{Fe})$ & $10 \mathrm{mg} / \mathrm{l}$ & $0.4 \mathrm{mg} / \mathrm{l}$ & $6 \mathrm{mg} / \mathrm{l}$ \\
\hline *PAH as Benzo (b) fluoranthene & $0.01 \mathrm{ug} / \mathrm{l}$ & $0.0063 \mathrm{ug} / \mathrm{l}$ & $0.1 \mathrm{ug} / \mathrm{l}$ \\
\hline $\mathrm{pH}$-Value & 7.9 & 8.2 & $6.0-8.5$ \\
\hline
\end{tabular}

* PAH as Benzo (b) fluoranthene: This was not tested during the treatability trials. However, data on concentrations present in the leachate were supplied by the employer. On most occasions the concentration was below the recorded limit of detection $<0.023 u g / l$. A marginally higher value of $<0.046 u g / I$ was recorded in the sump in February 2015 and January 2016. All these values are well below the Discharge Permit value of 0.1 ug/l, thus it is reasonable to assume a design blend value of $<0.1 \mathrm{ug} / \mathrm{l}$.

chate passing through the plant, hence the strong correlation with changing leachate volumes, shown in Figure 16.

Both COD and Ammoniacal-N loading are highest during winter months, from December to February. In contrast, during the autumn months (September to November), the loading for COD and Ammoniacal-N are at their lowest, corresponding with the significantly reduced rainfall when compared to other seasons. This seasonal loading variation is typical of leachate at many other landfill sites.

Because significantly higher volumes of leachate are treated during winter months, this causes elevated loading of both COD and ammoniacal-N. Table 4 shows that ammoniacal-N loading of $5,694 \mathrm{~kg}$ during the winter months (December to February) is approximately double the loading of $2,913 \mathrm{~kg}$ during autumn (September to November).

Although the volumes of leachate generated at Bleakdown vary significantly on a seasonal basis, it is clear that the loading of Ammoniacal- $\mathrm{N}$ throughout the year is not altered drastically, due to the varying strength of leachate at different times of year.

Figure 12 shows that the feed ammoniacal-N strength varies by a factor of $\sim 5$ over the course of a year, whilst Figure 11 shows monthly leachate volumes vary by a factor of $\sim 10$. Because these two parameters are inversely correlated, the net effect is that the ammoniacal- $\mathrm{N}$ loading only varies by a factor of $\sim 2$. Whilst this inverse correlation of leachate flow and strength fluctuations is common knowledge in a qualitative sense, this case study highlights a real data set, in order to quantify the extent of seasonal variations that can occur in both parameters, and the net effect this has on loading.

Regardless of the loading that the LTP experiences on a seasonal basis at Bleakdown Landfill Site, Table 3 proves that the treatment plant has been capable of consistently achieving the discharge consent as applied to the site by the UK Environment Agency.

\subsection{Biological sludge concentrations}

As noted earlier, the low concentrations of ammoniacal-N (17.5 mg/l) and BOD (2.23 mg/l) combined with the high concentrations of iron (10 mg/l) and calcium (150 $\mathrm{mg} / \mathrm{l})$, could lead to the depletion of organic solids and the accumulation of inorganic solids within the SBR reactor at Bleakdown LTP. It is worth noting that the long term mean BOD concentration of $2.23 \mathrm{mg} / \mathrm{l}$ within the Bleakdown leachate is much lower than the original concentration of 28 $\mathrm{mg} / \mathrm{l}$ litre that was used during the trials.

Figure 17 shows that occasional reseeding of biological sludge was needed, as was noted during the treatability trials. Following the initial seeding of the treatment plant, three additions of biological sludge have been required in order to maintain levels of organic matter within the SBR. These additions were made at between 10 and 12-month intervals, and were low cost to the process, because only a single small $\left(18 \mathrm{~m}^{3}\right)$ tanker of concentrated sludge was required to be delivered to site.

On each occasion, sludge levels within the SBR reduced initially, before stabilising at a concentration that could be maintained for up to a 12-month period. Volatile suspended solids concentrations (VSS) have always changed proportionally to the total suspended solids (TSS), reducing significantly following reseeding, before stabilising at a lower concentration and eventually requiring an addition of fresh biological sludge after a 10 to 12-month period.

During July 2019, a modification was made to the leachate feeding arrangement, which meant that the discharge bellmouth was flushed before the effluent was decanted. This was to ensure that no sludge accumulated within the bellmouth prior to decant. The impact of this simple modification can be seen in Figure 17, when following the modification and addition of sludge, the rate of sludge loss was reduced significantly. Additionally, it is worth noting that suspended solids have never been a problem within the effluent being discharged to the local stream.

Going forwards, it is predicted that biological sludge additions into the SBR at Bleakdown will be necessary at less frequent periods of greater than 12 months. 


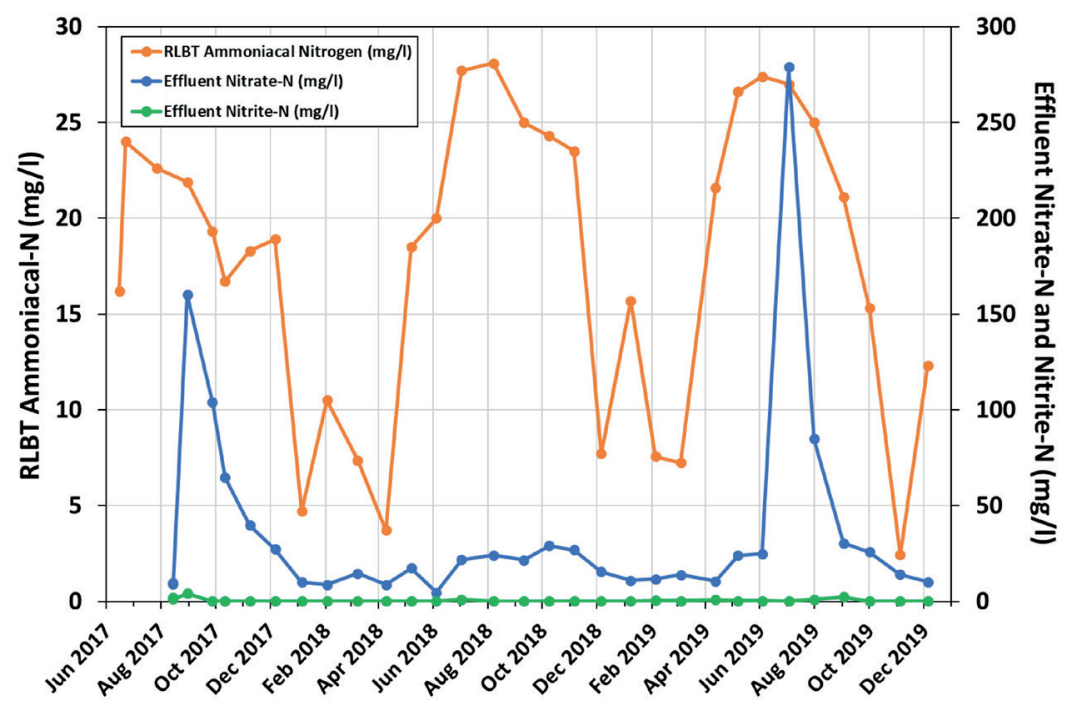

FIGURE 12: RLBT Ammoniacal-N concentration and Effluent Nitrate-N and Nitrite-N concentrations.

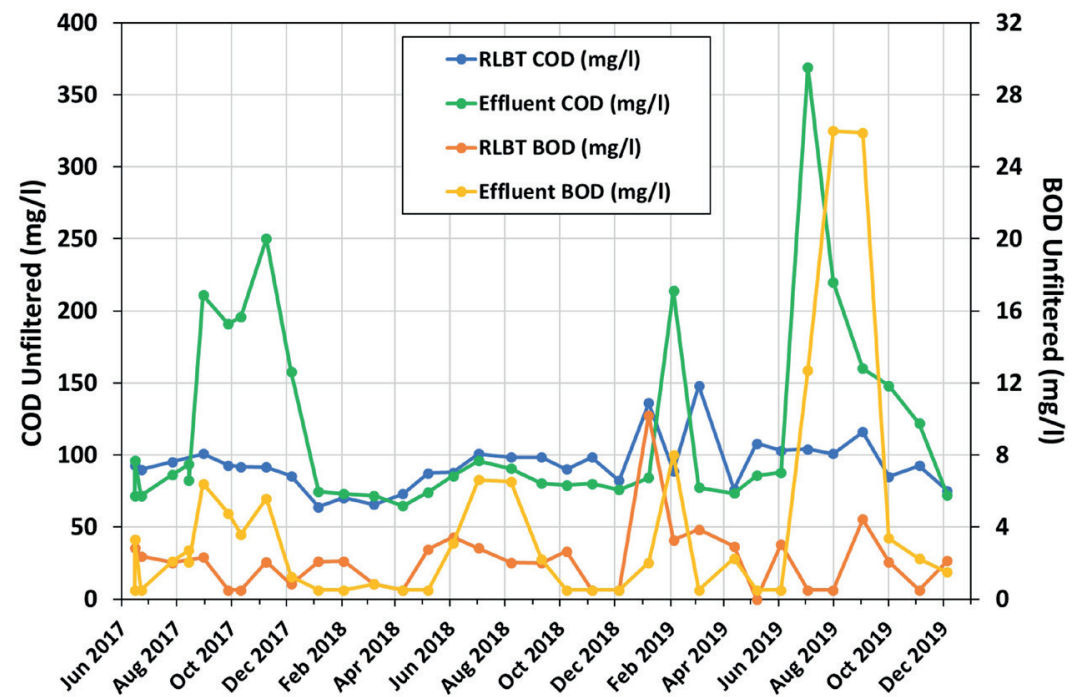

FIGURE 13: Raw leachate COD and BOD concentrations, compared with Effluent COD and BOD concentration.

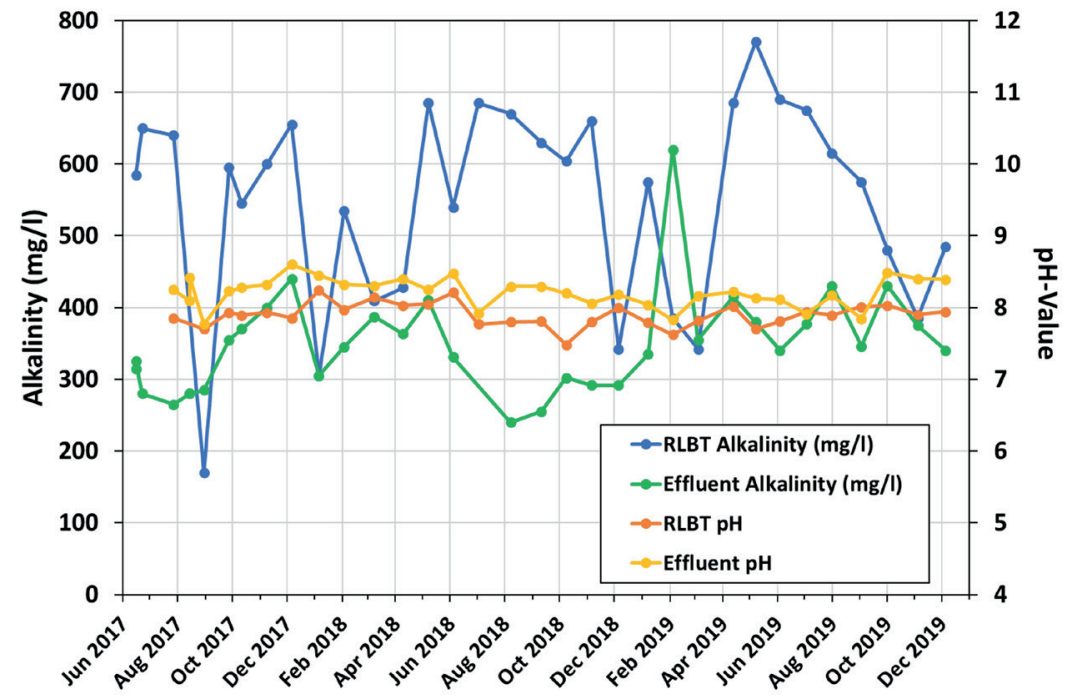

FIGURE 14: Raw leachate alkalinity and pH-value, compared with Effluent alkalinity and pH-value. 


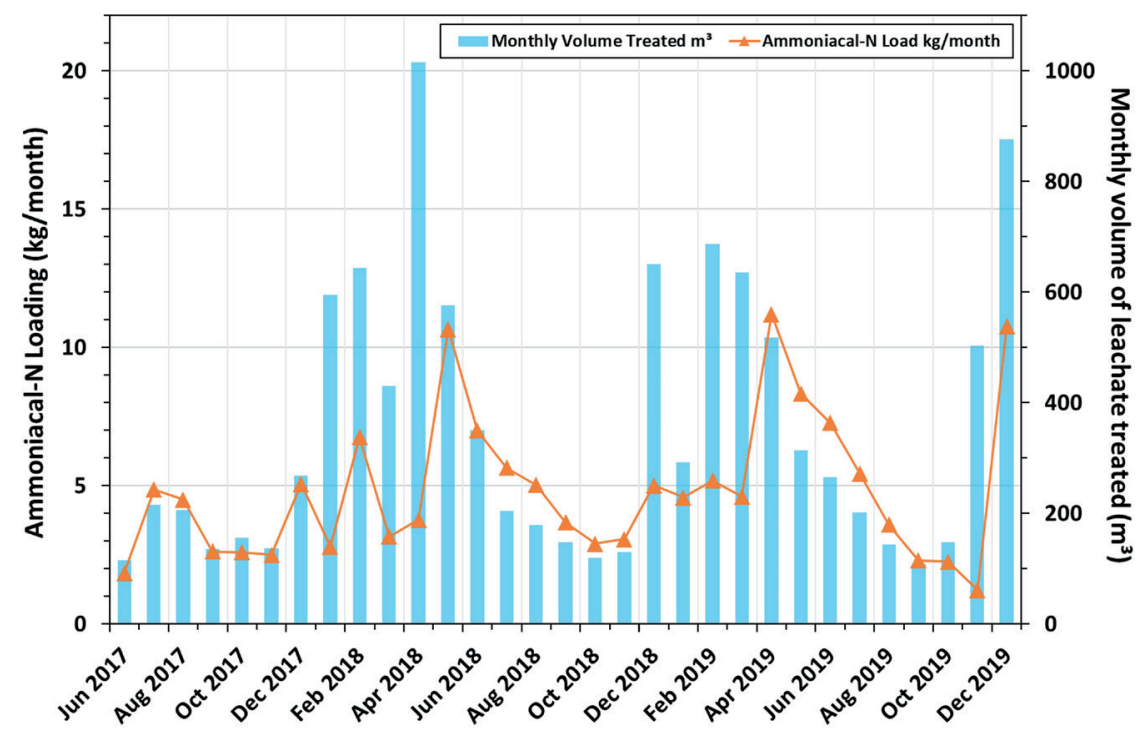

FIGURE 15: Ammoniacal-N loading results compared to the volumes of leachate treated by the LTP since biological commissioning during June 2017.

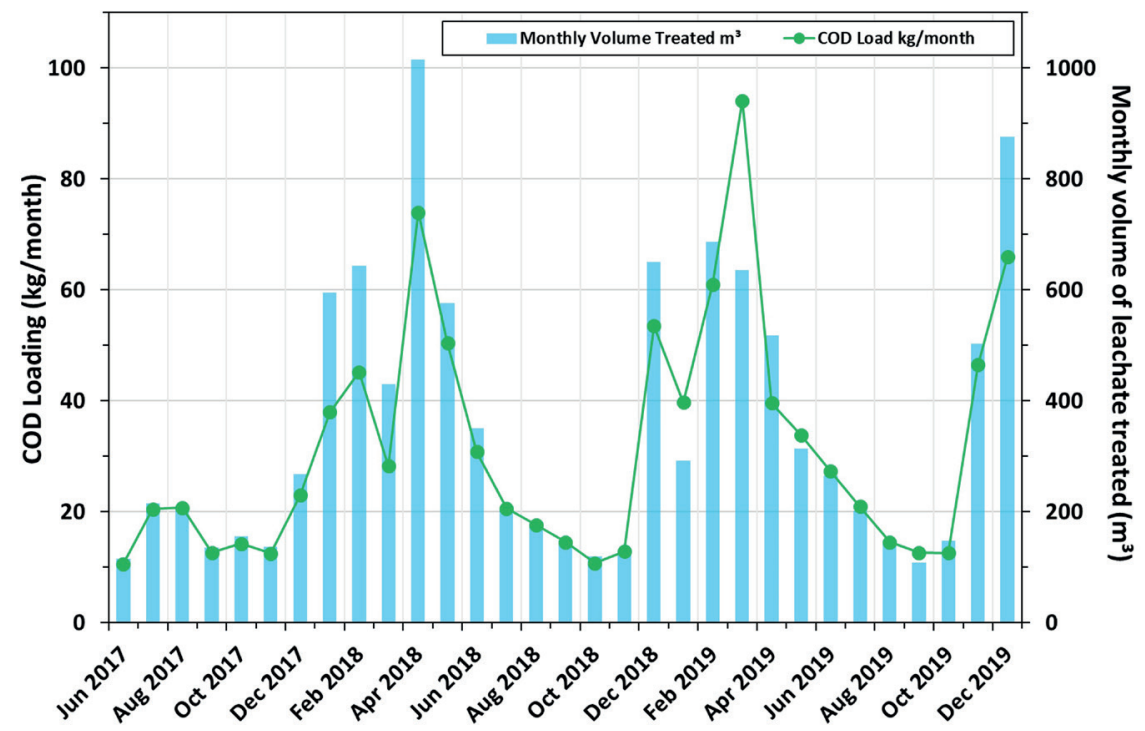

FIGURE 16: COD loading results compared to the volumes of leachate treated by the LTP since biological commissioning during June 2017.

\section{FUTURE OPERATION OF THE TREATMENT PLANT}

Having now operated successfully for more than two years, it is expected that the Bleakdown LTP will continue to fulfil its purpose in successfully treating the leachate abstracted from this landfill site.

A key factor in the ongoing success of the treatment plant is the routine testing, monitoring and sampling work performed at the plant. This work enables assessment of the effectiveness of the treatment plant, and the successful operation of all elements of Bleakdown LTP. The regular sampling enables observations to be made as to whether the treatment plant is achieving its design capacity, and also helps in monitoring any unexpected changes in leachate strength.
By regularly testing the SBR reactor for concentrations of suspended solids and volatile suspended solids, a record can be kept of the total organic sludge content within the process. This is beneficial because it means that any changes in sludge concentration can be addressed before any problems arise. At a small and simple treatment plant such as this, where relatively small volumes of leachate are being treated, it is only now an occasional requirement for biological sludge to need reseeding.

\section{CONCLUSIONS}

This paper presents a case study of Bleakdown Leachate Treatment Plant, which is a completely unmanned and remote site, where monitoring technicians are only required to briefly attend site twice per month in order to 


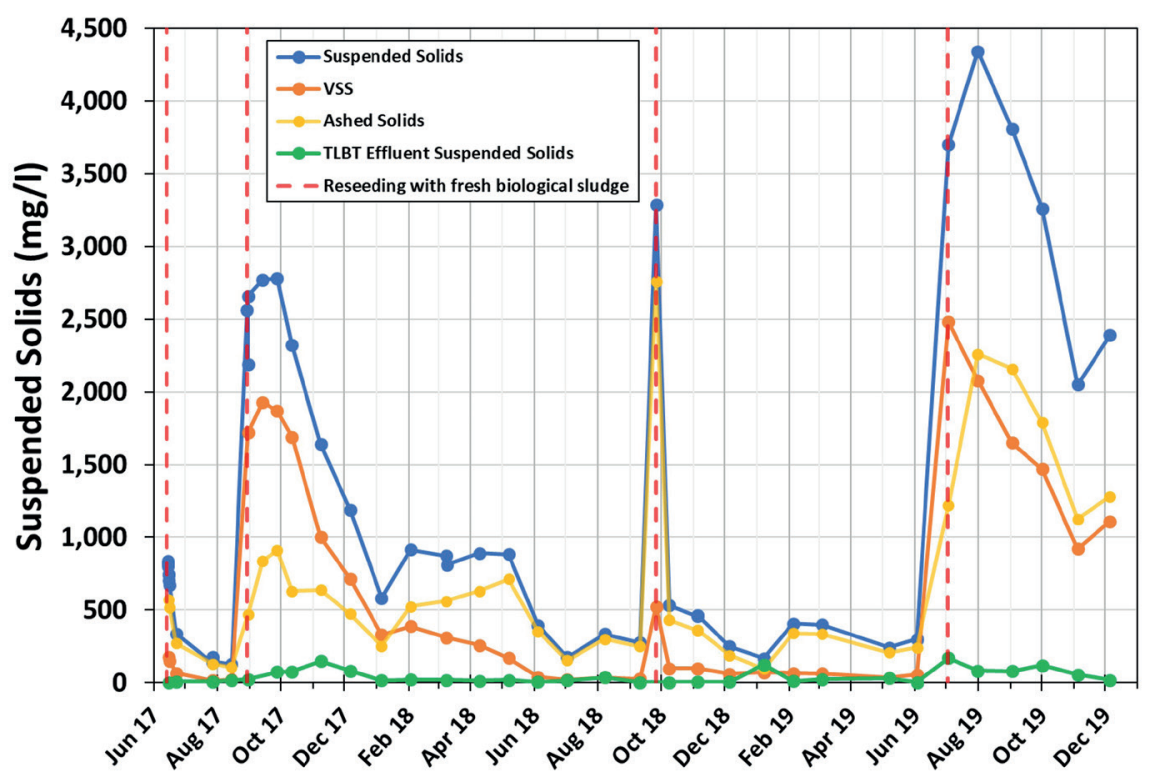

FIGURE 17: Suspended solids, volatile suspended solids and inorganic solids within the SBR reactor at Bleakdown LTP, following commissioning in June 2017 up to December 2019.

monitor the biological process. Through an online SCADA control system, operation of the treatment plant can be monitored and controlled remotely, trends in results observed, and daily data and treatment records downloaded.

Routine reporting following monitoring and maintenance checks made on the site is used to inform Phoenix Engineering that the process is working effectively, and analytical results obtained from monthly sampling exercises support on site observations and analysis.

This treatment plant is a prime example of how leachate from old closed landfills can be effectively managed, with very low costs of operation, maintenance and site attendance, when compared to alternative solutions. In future it is expected that many more of these similar leachate treatment plants will be necessary at old, closed landfill sites, where relatively weak leachates are being generated and require treatment in order for stringent discharge consents to be achieved.

\section{AKNOWLEDGEMENTS}

Phoenix Engineering would like to acknowledge the assistance and cooperation of our client, Aggregate In- dustries throughout the operation and maintenance of the Bleakdown leachate treatment plant and landfill site.

Phoenix would also like to thank both Tim Wilkins and CEC Systems for their support and efforts in carrying out routine maintenance, monitoring and sampling works at the leachate treatment plant.

\section{REFERENCES}

Carville, M., Last, S., Olufsen, J. and Robinson, H., (2003). Characterisation of contaminant removal achieved by biological leachate treatment systems. Paper presented to Sardinia 2003, the International Waste Management and Landfill Symposium, S. Margherita di Pula, Cagliari, Italy, 6-10 October 2003, 10pp.

Last, S., Barr, M., Robinson, H., (1993). Design and operation of Harewood Whin landfill: an aerobic biological leachate treatment works. Paper presented to an open meeting of the North East Centre of the Institute of Wastes Management, held at Askham Bryan Agricultural College, York, on 12 March 1993. 10pp plus figures and plates. Published in Wastes Management Proceedings, October 1993, 9-16.

Robinson, H., Maris, P.J., (1983). The Treatment of Leachates from Domestic Wastes in Landfills : I. Aerobic Biological Treatment of a Medium-strength Leachate. Water Research, 17(11), 1537-1548, November 1983.

Robinson, H., Grantham, G., (1988). The treatment of landfill leachates in on-site aerated lagoon plants : Experience in Britain and Ireland. Water Research, 22 (6), June 1988, 733-747.

TABLE 4: Mean seasonal Ammoniacal-N and COD concentrations and loadings at Bleakdown since June 2017.

\begin{tabular}{|c|c|c|c|c|}
\hline Season & Spring & Summer & Autumn & Winter \\
\hline Determinand & March - May & June - Aug & Sept - Nov & Dec - Feb \\
\hline $\operatorname{COD}(\mathrm{mg} / \mathrm{l})$ & 93.1 & 95.2 & 93.9 & 87.8 \\
\hline COD loading (total kg) & 22,780 & 20,130 & 12,900 & 45,870 \\
\hline Ammoniacal- $\mathrm{N}$ as $\mathrm{N}$ (mg/l) & 14.2 & 24.0 & 21.2 & 10.9 \\
\hline Ammoniacal-N loading (total kg) & 3,480 & 5,070 & 2,910 & 5,690 \\
\hline Mean monthly rainfall (mm/month) & 69.5 & 63.2 & 54.0 & 73.0 \\
\hline Mean monthly treated leachate volume ( $\left.\mathrm{m}^{3} / \mathrm{month}\right)$ & 245 & 211 & 137 & 522 \\
\hline
\end{tabular}


Robinson, H., (1989). On site treatment of leachates from landfilled wastes. Paper presented to the annual conference of the Institution of Water and Environmental Management, IWEM 89 "Technology Transfer in Water and Environmental Management, at the Metropole Hotel, National Exhibition Centre, Birmingham, 12-14 September 1989. 1 Paper 15, 18pp, in Proceedings, and published in the Journal of the Institution of Water and Environmental Management, 4, (1), February 1990, 78-89.

Robinson, H., (1990). On-site treatment of leachates from landfilled wastes. Journal of the Institution of Water and Environmental Management, 4 (1), February 1990, 78-89.

Robinson, H., Luo, M.M.H., (1991). Characterisation and treatment of leachates from Hong Kong Landfill Sites. Journal of the Institution of Water and Environmental Management, 5 (3), June 1991, 426335.

Robinson, H., (1992). Leachate collection, treatment and disposal. Paper presented at the Institution of Water and Environmental Management Conference, "Engineering of Landfill - Problems and Solutions", held at the Wiltshire Hotel, Swindon, on 30 October 1991, 22pp. Published in the Journal of the Institution of Water and Environmental Management, 6 (3), June 1992, 321-332.

Robinson, H., (1995). A Review of the Composition of Leachates from Domestic Wastes in Landfill Sites. Report No. CWM/072/95, prepared for the Wastes Technical Division of the UK Department of the Environment, under contract number PECD/7/10/238, in the series "The Technical Aspects of Controlled Waste Management". August 1995, 550pp.

Robinson, H., Chen, C.K., Formby, R., Carville, M., (1998). Leachate treatment plants at Hong Kong landfill sites. International training seminar, Management and treatment of MSW landfill leachate. Cini Foundation, San Giorgio Venice, December 1998.

Robinson, H., Harris, G., Last, S., (1999). The stripping of dissolved methane from landfill leachates prior to their discharge into sewers. Paper presented to Sardinia 99, the Seventh International Waste Management and Landfill Symposium, S. Margherita di Pula, Cagliari, Italy, 4-8 October 1999, Proceedings Volume II, 285293pp.

Robinson, H., (2000). Major UK study of trace contaminants in landfill leachate. Waste Management, April 2000, page 26.

Robinson, H., Knox, K., Van Santen, A., Tempany, P.R., (2001). Compliance of UK landfills with EU pollution emissions legislation: development of a reporting protocol. Paper presented to Sardinia 2001, the Eighth International Waste Management and Landfill Symposium, S. Margherita di Pula, Cagliari, Italy, 1-5 October 2002, 10pp.

Robinson, H., Knox, K., (2001). Pollution Inventory discharges to sewer or surface water from landfill leachates: Final Report to the UK Environment Agency, by Enviros and Knox Associates. Ref: REGCON 70, May 2001. 19pp plus Appendices and Figure.

Robinson, H., Knox, K., (2003). Updating the Landfill Leachate Pollution Inventory tool: Report to the UK Environment Agency by Enviros and Knox Associates. R\&D Technical Report No. PI - 496/TR (2), March 2003, 56pp.

Robinson, H., Farrow, S., Last, S., Jones, D., (2003). Remediation of leachate problems at Arpley Landfill Site, Warrington, Cheshire, UK. Paper presented to Sardinia 2003, the Ninth International Waste Management and Landfill Symposium, S. Margherita di Pula, Cagliari, Italy, 6-10 October 2003, 10pp.

Robinson, H., Carville, M., Walsh, T., (2003). Advanced leachate treatment at Buckden Landfill, Huntingdon, UK. Journal of Environmental Engineering and Science, 2, (4), 255-264, July 2003.
Robinson, H., Olufsen, J., Last, S., (2004). Design and operation of cost-effective leachate treatment schemes at UK Landfills: Recent case studies. Paper presented to the 2004 CIWM Annual Exhibition and Conference, June 2004, Torbay.

Robinson, H., (2007). The composition of leachates from very large landfills: An international review. Paper presented to Torbay 2006, The Annual Conference and Exhibition of CIWM "Changing the Face of Waste Management", Paignton, June 2006. Published in Communications in Waste and Resource Management, June 2007, 8 (1), pp. 19-32.

Robinson, H., (2008). Operation of the UK's largest leachate treatment plant : 6 years of experience at Arpley Landfill. Paper presented to Waste 2008, "Waste and Resource Management - A Shared Responsibility", held at the Stratford Manor Hotel, Stratford-upon-Avon, Warwickshire, England, 16-17 September 2008, In Proceedings, $10 \mathrm{pp}$.

Robinson, H., Carville, M., Robinson, T., (2013). Biological Nitrification and Denitrification of Landfill Leachates. Paper presented to Sardinia 2013, the Fourteenth International Waste Management and Landfill Symposium, S. Margherita di Pula, Cagliari, Italy, 30 September - 4 October 2013, Proceedings P95 and on DVD ROM.

Robinson, H., Wilson, K., Stokes, A., Olufsen, J., Robinson, T., (2017). Recent state-of-the-art leachate treatment plants in eastern England. Paper presented to Sardinia 2017, the Sixteenth International Waste Management and Landfill Symposium, S.Marguerita di Pula, Cagliari, Italy, 2 - 6 October 2017, in Proceedings.

Robinson, T., (2013). Aerobic Biological Treatability Studies on Landfill Leachate using Nitrification and Denitrification. Paper presented to Sardinia 2013, the Fourteenth International Waste Management and Landfill Symposium, S.Marguerita di Pula, Cagliari, Italy, 30 September - 4 October 2013, 9pp, in Proceedings.

Robinson, T., (2014). Aerobic Biological Treatability Studies on Landfill Leachate using Nitrification and Denitrification. Final Year Dissertation Project 2014, School of Environmental Sciences, University of East Anglia, Norwich, UK, 100 pages, Available from the UEA Library.

Robinson, T., (2015). Use of pilot-scale treatability trials in the design of full-scale leachate treatment plants. Paper presented to Sardinia 2015, the Fifteenth International Waste Management and Landfill Symposium, S.Marguerita di Pula, Cagliari, Italy, 5 - 9 October 2015, 128pp in Proceedings.

Robinson, T., (2017). Robust and reliable treatment of leachate at a closed landfill site in Sussex, UK. Paper presented to Sardinia 2017, the Sixteenth International Waste Management and Landfill Symposium, S.Marguerita di Pula, Cagliari, Italy, 2 - 6 October 2017, in Proceedings.

Robinson, T., (2018). Robust and reliable treatment of leachate at a closed landfill site in Sussex, UK. Detritus. 1 (1), Pages 116-121. Available at: https://digital.detritusjournal.com/articles/robustand-reliable-treatment-of-leachate-at-a-closed-landfill-site-in-sussex-uk/30

Robinson, T., (2019). Aerobic Biological Treatability Studies on Landfill Leachate with Nitrification and Denitrification. Detritus. 7 (1), Pages 1-13. Available at: https://digital.detritusjournal.com/articles/in-press/aerobic-biological-treatability-studies-on-landfill-leachate-with-nitrification-and-denitrification/235

Shuyler, R.G., (2013). What every operator should know about ORP. Water Environment and Technology, January 2013, 25, 68-69.

UK Department of the Environment (1978). Cooperative Programme of Research on the Behaviour of Hazardous Wastes in Landfill Sites: Policy Review Committee Final Report, April 1978. 